\title{
Effect of volatile organic compounds mediated fungal growth inhibition by Trichoderma asperellum HbGT6-07
}

Md Kamaruzzaman ( $\square$ kamaru.m@webmail.hzau.edu.cn )

Nanjing Agricultural University

Md. Samiul Islam

Huazhong Agricultural University

Shakil Ahmed Polash

RMIT University

Razia Sultana

Huazhong Agricultural University

\section{Research Article}

Keywords: Trichoderma asperellum, Botrytis cinerea, Sclerotinia sclerotiorum, Biological control, VOCs

Posted Date: February 18th, 2021

DOl: https://doi.org/10.21203/rs.3.rs-208439/v1

License: (c) (i) This work is licensed under a Creative Commons Attribution 4.0 International License. Read Full License 


\section{Abstract}

The species of Trichoderma are one of the most frequently used natural biocontrol agents to mitigate plant diseases and improve crop yields. In this study, sixteen Trichoderma spp. were isolated from soil of different regions of China. However, we identified Trichoderma. asperellum HbGT6-07 by initial fungal growth inhibition assay and molecular approach and also evaluated the antimicrobial effects. Tested $10 \%$ concentrated culture filtrate of $T$. asperellum HbGT6-07 inhibited $93 \%$ of colony radial growth in Botrytis cinerea (B05.10) as well as $91 \%$ of Sclerotinia sclerotiorum (A367).

VOCs emitted from HbGT6-07 have antimicrobial properties against Botrytis cinerea (B05.10) and Sclerotinia sclerotiorum (A367). In in-vitro DwD method, The T. asperellum HbGT6-07 volatile organic compounds (VOCs) effectively reduced colonial diameter, mycelial growth rate and sclerotia production by two virulent fungal pathogens. The GC-MS analysis identified thirty-two VOCs derived from HbGT6-07 isolates. Moreover, the hyphal fragments of the T. asperellum HbGT6-07 demonstrated successful mycelia growth suppression of two virulent fungal agents by competing toward the invasion on oilseed rape leaves. The above findings indicated that $T$. asperellum $\mathrm{HbGT6-07}$ could attain competitive progress via volatile antifungal compound production and comprehensive mycelial growth. This study provided an outlook of using $T$. asperellum $\mathrm{HbGT6-07}$ to control virulent pathogens of $B$. cinerea and S. sclerotiorum.

\section{Introduction}

Trichoderma is one of the most intensively studied genera of hypocrealean fungi because of its enormous agricultural, industrial, and environmental applications (Blaszczyk et al. 2014; Schuster and Schmoll 2010). This anamorphic fungal genus acts as a potential biocontrol agent (BCA) against minimum 18 genera and 29 pathogenic fungi members as well as a range of bacterial microbes since Trichoderma lignorum was eliminated Rhizoclonia solani microbial growth (Weindling 1932; Wu et al. 2017). Some species of Trichoderma can alleviate the pathogenic fungal infection of different soil-borne plants such as Colletotrichum spp. on mango (de los Santos-Villalobos et al. 2013) and sugar cane (Singh et al. 2014), Fusarium oxysporum on tomatoes (Segarra et al. 2010), Alternaria solanion tomatoes (Chowdappa et al. 2013; Fontenelle et al. 2011) and chilies (Begum et al. 2010), Sclerotinia sclerotiorum on common beans (Geraldine et al. 2013) and peas (Jain et al. 2015), Penicillium expansum on apple fruits (Batta 2004) and even Botrytis on onions (Elad et al. 1995); strawberries (Kovach et al. 2000) and Begonia (Horst et al. 2005). In agricultural sites, biocontrol agents based on Trichoderma species have been commercially occupying the majority of the fungicides in recent years and preventing soil-borne pathogens worldwide.

The mechanisms of action of Trichoderma spp. comprise mainly aggression and mycoparasitism, accompanied by plant-resistance, antifungal metabolite production, plant growth promotion, and immunity stimulation (Benítez et al. 2004; Harman 2006; Vos et al. 2014). The biological control ability of Trichoderma is different between species and isolates, and the mechanism of mycoparasitism may have little association with antagonism for the same isolates (Lopes et al. 2012), thus screening of 
Trichoderma isolates for biocontrol needs to consider several factors. In recent years, attempts have been devoted to discover and establish eco-friendly methods which are harmless to plant growth and human health (Schalchli et al. 2016). A significant number of research follows bio-control based strategy where different volatile organic compounds (VOCs) emitted from microorganism use to inhibit crop diseases causing microbes and thus referred as biopesticides (Glare et al. 2012). Several bioactive compounds generated by fungi which considered as a antimicrobials have been reported in the literature, including isonitrile, oligosaccharides, sesquiterpenes, polyketides, hydrogen cyanide, alkylpyrones, stemids, peptaibols, lytic enzymes, diketopiperazines, and lytic enzymes (Degenkolb et al. 2008; Heydari and Pessarakli 2010; Ownley et al. 2010). However, volatile metabolites released by Trichoderma spp. are considered to be active biocontrol agents (R. Hung et al. 2013; Menjivar et al. 2012; Suwannarach et al. 2013).

Volatile organic compounds (VOCs) produced by the species Trichoderma are of significant concern for the content of antifungal effects. VOCs have low molecular mass, higher steam pressure, low polarity, low melting points and quickly evaporate lipophilic substances at $25^{\circ} \mathrm{C}$ (room temperature) (Schulz-Bohm et al. 2017). Moreover, VOCs are chemically diverse and include aromatics, lactones, amines, alcohols, ketones, thiols, esters, cyclohexenes, terpenes, mono- and sesquiterpenes (Korpi et al. 2009; Schenkel et al. 2015). More than 300 distinct VOCs have been reported in the fungi, mostly known to be developed by different species of Trichoderma (Rahnama 2016; Siddiquee et al. 2012). Although VOCs are a tiny part of the overall compounds formed by Trichoderma spp. their unique characteristics enable antibiotic action against fungal pathogens (Lee et al. 2016; Nieto-Jacobo et al. 2017).

Soil VOCs are potential indicators of microbial community structure and community shifts (McNeal and Herbert 2009). However, many studies have shown that several plant and fungal VOCs have potent physiological effects where they act in signalling, communication, antagonism and inter- and intraspecific association. In recent years, more attention has been paid to VOC-mediated impacts, their ecological and biological importance and their effect in the growth of soil ecosystems (Bitas et al. 2013; D. T. Hung et al. 2015; Peñuelas et al. 2014). VOCs vary enormously in structure and composition where a single compound can influence multiple aspects of the growth and development of an organism. For instance, dimethyl disulfide, developed by plants and microbes, has numerous roles as an insect attractant, plant systemic resistance elicitor, and pathogenic fungus suppressor (Crespo et al. 2012; Kai et al. 2007). Microbial VOCs mixtures play a role in the development and control of symbiotic associations and the distribution of saprophytic, mycorrhizal and pathogenic species in the soil (Müller et al. 2013; Rigamonte et al. 2010).

The purpose of the study was to identify potential bioactive isolates of Trichoderma and to explain that VOCs have become a significant factor in the advancement of growing plants that could be applied directly as biocontrol agents. Finally, we used gas chromatography-mass spectrometry (GC-MS) analysis to classify the isolate-generated volatile status to evaluate the metabolites that were essential for the antifungal impacts. 


\section{Materials And Methods}

\section{Fungal isolates and culture conditions}

Trichoderma isolates were isolated from agriculture soil in different locations of China (Supplementary Table S1). Soil specimens were put in clean containers, delivered to the laboratory and held at $4{ }^{\circ} \mathrm{C}$ until they were used. The sample were prepared $10^{-4}$ serial dilutions in sterilised distilled water (SDW) and 500 $\mu \mathrm{L}$ sample (diluted) was spread on the potato dextrose agar (PDA) media plates and incubated at $20 \pm 2$ ${ }^{\circ} \mathrm{C}$ for $72 \mathrm{~h}$. The cultivation plates were checked frequently, and each visualised colony was known to be one colony-forming unit (CFU). Various fungal colonies were sub-cultured to PDA plates following the counting of CFU. For this analysis, B. cinerea strains B05.10 and one isolate (A367) of S. sclerotiorum were taken. Originally isolated B05.10 and A367 was obtained from grapes (Büttner et al. 1994), and eggplant (Magioli and Mansur 2005). The experimental cultures of the isolates were developed by shifting the mycelia to PDA plates, and incubated at $20^{\circ} \mathrm{C}$ between $5-10$ days under the 12-h dark-light regime.

\section{Assay of inhibition of B. cinerea and S. sclerotiorum growth by Trichoderma spp. through dual culture method}

For dual cultures, isolates of Trichoderma were screened for inhibition against $B$. cinerea B05.10 and $S$. sclerotiorum A367. The microbes and Trichoderma were cultivated for 5-6 days at a temperature of $20 \pm 2$ ${ }^{\circ} \mathrm{C}$ on PDA plates. Mycelium agar plug (MAPs, $5 \mathrm{~mm}$ in diameter) of the target necrotrophic fungus ( $B$. cinerea and $S$. sclerotium) collected from the periphery and inserted onto new PDA dishes. After 2 days incubation of Trichoderma spp. the fungal discs were moved aseptically in the center of the target fungi plate and were kept at $25^{\circ} \mathrm{C}$ with intermittent light-dark conditions for 10 days and monitored frequently. Triplicates were used in each study, and after 10 days of constant growth of $B$. cinerea and $S$. sclerotium colonies, the degree of the invasion was estimated and the control (pure cultures of $B$. cinerea and $S$. sclerotium) was compared. The fungal growth inhibition zone formula was estimated by I $=(\mathrm{C}-\mathrm{T}) / \mathrm{C} \times$ 100 , where $C$ is the growth of mycelium in the control plate, $T$ is the test species growth of mycelium in the inserted plate, and $I$ is the mycelial growth inhibition (Wonglom et al. 2019). Each experiment was done three times, with three replications each time. Finally, the plates where Trichoderma colony completely covered by $B$. cinerea or $S$. sclerotium colony surface was selected as a super isolate.

\section{Biological characterization of isolates HbGT6-07}

According to the protocol of Samuels et al. 2002, the phenotypic and cultural properties of Trichoderma asperellum HbGT6-07 isolates were analyzed in numerous media viz. PDA, SDA, CDA, CPA, MM, MMN, MYA, YMEA, YPG, and YSS (Samuels et al. 2002). Mycelial discs of developing isolates HbGT6-07 were inoculated at the edge of the Petri plates that included earlier in this section-mentioned media and incubated at $25 \pm 2{ }^{\circ} \mathrm{C}$ for a week. Colony radius was calculated at 24,48 , and $72 \mathrm{~h}$ intervals. The test was replicated three times, and the tests for each isolate were averaged. External characteristics including the presence of pigments, green conidia, odor and colony appearance are also noted. Morphological 
findings from mycelial growth on PDA plates have been reported. Thus every feature was calculated in $3 \% \mathrm{KOH}$ for each isolate from the water after preliminary soaking.

\section{Genomic DNA extraction, PCR amplification and phylogenetic tree analysis}

Isolates HbGT6-07 with the strongest inhibition against $B$. cinerea and S. sclerotiorum growth was further identified through the analysis of its $5.8 \mathrm{~S}$ rDNA sequence. Genomic DNA were extracted by cetyltrimethylammonium bromide (CTAB) method (M Kamaruzzaman et al. 2018) and DNA was dissolved in $50 \mu \mathrm{l}$ TE buffer fluid to create DNA suspension and quantified using fluorescence of ethidium bromide (Raeder and Broda 1985). Then PCR amplification was done by using the universal primers ITS1 (3'-TCCGTAGGTGAACCTGCGG-5') and ITS4 (3'-TCCTCCGCTTATTGATATGC-5'). A total volume of $25 \mu \mathrm{l}$ of reaction mixture was used for PCR amplification. Every reaction comprises $0.2 X$ PCR buffer, $0.16 \mathrm{mM}$ $\mathrm{MgCl}_{2}, 0.01 \mu \mathrm{M}$ ITS1 (forward primer), $0.01 \mu \mathrm{M}$ (reverse primer), $0.144 \mathrm{mM} \mathrm{dNTP}, 0.5 \mathrm{mU} / \mu \mathrm{l} \mathrm{Taq}$ polymerase, $2.00 \mu \mathrm{l}$ template DNA and $14.95 \mu \mathrm{l} \mathrm{PCR}$ water, respectively. The initial denaturation of these reactions was $90 \mathrm{~s}$ at $95^{\circ} \mathrm{C}$, followed by 30 cycles of $1 \mathrm{~min}$ at $95^{\circ} \mathrm{C}, 30 \mathrm{~s}$ at $55^{\circ} \mathrm{C}$ and $1.5 \mathrm{~min}$ at $72{ }^{\circ} \mathrm{C}$, with a final extension of $10 \mathrm{~min}$ at $72{ }^{\circ} \mathrm{C}$ and a final hold of $4{ }^{\circ} \mathrm{C}$. The PCR band were visualized using a $1 \%$ agarose gel. PCR products were cloned in E. coli DH5a with vector PMD18-T (You et al. 2016) and sequenced by Wuhan Tianyi Huiyuan Biological Technology Co., Ltd, Hubei, China. The obtained sequence was submitted to GeneBank to get the accession number. Multiple sequence alignments and comparisons with reference strain for each of the genes were performed through the aid of CLUSTALW and Neighbour-joining method was used to constructed phylogenetic tree topologies by performing bootstrap values of 1000 data sets using MEGA7.0 (Molecular Evolutionary Genetic Analysis) tools. The corresponding sequence accession numbers are listed in Supplementary Table S2 for constructing phylogenetic tree analyses. The sequence was deposited to GeneBank under the mentioned accession number: $\mathrm{MH} 280010$.

\section{Preparation of the Culture Filtrate (CF) of Trichoderma asperellum HbGT6-07}

Two blocks of a 7-day-old HbGT6-07 mycelia agar plug (5 mm diameter) was inoculated in a $250 \mathrm{~mL}$ conical flasks containing $150 \mathrm{~mL}$ of sterilized potato dextrose broth (PDB) and cultured in an electrical shaker for 7 days at $150 \mathrm{rpm}$ and $22^{\circ} \mathrm{C}$. Then, the fermented outcome was centrifuged at room temperature at $10,000 \mathrm{rpm}$ for $10 \mathrm{~min}$ to remove the mycelium debris. Then, the obtained supernatant was collected after the pass through a $0.22 \mu \mathrm{m}$ membrane filter (Millipore Sigma, USA).

\section{The HbGT6-07 CF influenced the growth and morphology of $B$. cinerea and S. sclerotiorum}

B. cinereaand S. sclerotiorum were separately inoculated on PDA and cultured at $20^{\circ} \mathrm{C}$. Purified $\mathrm{CF}$ of HbGT6-07 were used in PDA plate to evaluate the effects on the mycelial radial growth of $B$. cinerea $S$. sclerotiorum. In the experiment, the select concentrations of the $\operatorname{CF}(10 \%, 6 \%, 2 \%$, and $1 \%(\mathrm{~V} / \mathrm{V}))$ were mixed with PDA, while sterile dd water was mixed with PDA used as a control (0\%). treatment. One threedays-old mycelial agar plug ( $5 \mathrm{~mm}$ in diameter) of $B$. cinerea was put in the middle of each petri dish and incubated at $20 \mathrm{C}$. Similarly, S. sclerotiorum mycelial agar plug as used. Each treatment was done with 
three replications. Five days after incubation, the colony diameter of each dish was calculated in two reverse directions, and the growth inhibition percentage (\% GI) of HbGT6-07 was calculated using the formula $\% \mathrm{GI}=[$ (mean of colony diameter in control - mean of colony diameter in treatment $) /$ mean of colony diameter in control] $\times 100$ (Hao et al. 2020). This experiment was repeated three times.

\section{The application of mycelial hyphal fragments to inhibit the necrotic diseases lesion}

Rapeseed oil plants seeds were planted in plastic pots with organic culture mix including $2 \%-5 \% \mathrm{~N}+$ $\mathrm{P}_{2} \mathrm{O}_{5}+\mathrm{K}_{2} \mathrm{O}\left(\mathrm{N}: \mathrm{P}_{2} \mathrm{O}_{5}: \mathrm{K}_{2} \mathrm{O}=1: 1: 1, \mathrm{w}: \mathrm{w}: \mathrm{w}: \mathrm{w}\right)$. The pots were placed in a chamber for plant growth where water was needed. The plants were softened to one seedling per pot at the multiple-true-leaf level (45-d old). Isolates HbGT6-07, B05.10 and A367 were individually cultured at $20^{\circ} \mathrm{C}$ below $12 \mathrm{~h}$ light-dark intervals on CF-PDA for $5 \mathrm{~d}$, and the subsequent mycelial volumes of every isolates were obtained and mixed in PDB to create hyphal fragments (HF) filtrates at a density of roughly $3 \times 10^{6} \mathrm{HF}$ per $\mathrm{mL}$ (Supplementary Fig. S1). HbGT6-07 HF mixture was combined with B05.10 HF suspension comprising hyphal segments (HFB05.10) at density proportions 6.6:3.3, 5:5 and 3.3:6.6, or coupled with A367 HF mixture also containing hyphal segments (HFA367) at the similar size ratio.

Every one of such HF mixtures were considered as inoculum in double isolates. They were lifted on the upper portion of the $5 \mathrm{~mm}$ diameter size of filter paper discs (FPD) positioned on rapeseed leaves to assist strengthen the inoculum, $25 \mu \mathrm{L}$ culture on each FPD, single FPD around each leaf, and five plants per inoculum (a total of 12 to 15 leaves per inoculum). HFS ${ }^{\mathrm{HbGT6}-07}$ acts as negative control, $\mathrm{HF}^{\mathrm{B} 05.10}$ or $\mathrm{HF}^{\mathrm{A} 367}$ alone used as a positive control. Most of the plants were kept in a humid cabinet at $20^{\circ} \mathrm{C}$ for three days in 12-h light-dark conditions. The leaf lesion diameter was estimated on the growth of leaves around each FPD. The following formula was used to calculate the biocontrol efficacy by the treatment of HbGT6-07 (BE ${ }^{\mathrm{HbGT6}-07 \mathrm{HFs}}$ ) hyphal fragments:

$\mathrm{BE}^{\mathrm{HbGT6-07} \mathrm{HFs}}=\left\{\left(\mathrm{AD}^{\text {Positive control}}-\mathrm{AD}^{\text {Treatment HFs }}\right) / \mathrm{AD}^{\text {Positive control }}\right\} \times 100 \%$

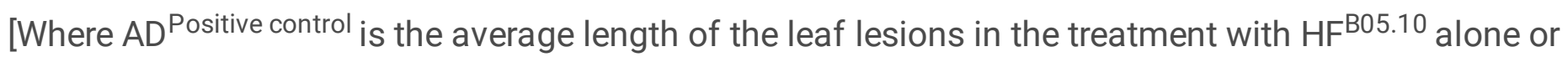
$H F^{A 367}$ by itself as an inoculum, while $A D^{\text {Treatment } H F s}$ is the average length of the leaf lesions in the $\mathrm{HF}^{\mathrm{HbGT6}-07}$ treatment with $\mathrm{HF}^{\mathrm{B} 05.10 \text { or }} \mathrm{A}^{367}$ treatment at the stated $\mathrm{HF}$ ratio]. Repeated the test three more times.

\section{Effect of mixed culture on sclerotia production}

Sterilized carrots were used as a carrier for sclerotia reduction experiment. Briefly, about $75 \mathrm{~g}$ carrots were cut into pieces $\left(1.5-2.5 \mathrm{~cm}\right.$ in size) and sterilized at $121^{\circ} \mathrm{C}$ for $30 \mathrm{~min}$ in a $250 \mathrm{~mL}$ conical flask. Five actively growing MAPs of B05.10 or A367 were placed inside the conical flask used as control. The mycelial mixtures (5 MAPs of HbGT6-07 + 5 MAPs B05.10) or (5 MAPs of HbGT6-07 + 5 MAPs of A367) were used in two separate treatments. Six conical flasks of each treatment were inoculated at $20^{\circ} \mathrm{C}$ for 15 
d. The average number of sclerotia and weight per flask were calculated. This experiment was repeated twice.

\section{Antifungal volatiles production by Trichoderma asperellum HbGT6-07}

In order to check the antifungal activity of the T. asperellum HbGT6-07 volatiles, Dish-within-Dish (DwD) sets method was performed where includes composed of one pair of the dish, a small inside dish $(6 \mathrm{~cm}$ in diameter) and a big outside dish (16 cm in diameter). For this study, B. cinerea isolate B05.10 was selected as a fungal target to evaluate the antimicrobial efficacy of the volatiles generated by HbGT6-07. There were three DwD sets for the three treatments. AWG in a $250 \mathrm{~mL}$ Erlenmeyer flask containing $100 \mathrm{~g}$ AWG was inoculated with four MAPs of HbGT6-07 or B05.10 or A367 $\left(20^{\circ} \mathrm{C}\right)$. In the case of B05.10, blank AWG (50 g) alone in the internal dish and B05.10 on AWG $(50 \mathrm{~g})$ in the external dish are defined as the first DWD set and considered as negative regulation. In the case of B05.10, blank AWG (50 g) individually in the inner dish and B05.10 on AWG (50 g) in the outer dish are known as the first DwD set and considered as a negative control. The third DwD set was B05.10 in both plates, it was known as B05.10/B05.10, that were chosen to remove the effect of $\mathrm{HbGT6-07} \mathrm{O}_{2}$ consumption and/or $\mathrm{CO}_{2}$ development on the radial formation of B05.10 in the outer plates in the inside plates. The three DwD groups were first developed by examining the inner dishes, where the B05.10 was left empty, inoculated with HbGT6-07 (one MAP each plate), or seeded with B05.10 (one MAP for each plate), and put in an incubator at $20^{\circ} \mathrm{C}$ below $12 \mathrm{~h}$ light-dark intervals for $20 \mathrm{~d}$. Next, B05.10, one MAP for every dish at a length of $5.5 \mathrm{~cm}$ from the internal dish was seeded on the external dishes (Supplementary Fig. S2). Specific techniques have been employed to establish the DwD sets against $S$. sclerotiorum A367 to recognise antimicrobial behaviour of HbGT6-07 volatile components. The resulting filtrates were incubated at $20^{\circ} \mathrm{C}$ under $12 \mathrm{~h}$ light-dark conditions for $5 \mathrm{~d}$ and used as the volatile origin in the subsequent DiD sets (inner dish/outer dish): fresh AWG / A367 (a negative control), HbGT6-07/A367 AWG culture, and A367 AWG culture (another negative control). Simultaneously with the loading of the fresh AWG, the AWG culture of HbGT6-07 and the AWG culture of A367 in the internal dishes, A367 MAPs from a 3-day PDA culture $\left(20^{\circ} \mathrm{C}\right)$ were incubated in the external dishes. The DWD sets were covered to parafilm and incubated for $20 \mathrm{~d}\left(20^{\circ} \mathrm{C}\right)$. The DwD sets were covered separately with parafilms (Parafilm M, Chicago, USA) and held at $20^{\circ} \mathrm{C}$ for the next $20 \mathrm{~d}$. Diameters of the B05.10 or A367 colony were calculated in each inner dish. Meanwhile, the regular growth rate, colony length, and sclerotia generated in the B05.10 or A367 colony were recorded and measured in each outer platter. The procedure was replicated once in each repetition, with three replicates per test.

\section{Gas chromatography/Mass spectrometry (GC-MS) analyses}

Using the GC-MS experiment, the chemical elements of the HbGT6-07 VOCs have been quantified. $T$. asperellum HbGT6-07 was cultivated in a $250 \mathrm{ml}$ Erlenmeyer sterile flask including $100 \mathrm{~mL}$ PDA with 6 pcs MAPs. The mycelial cultures were placed in a $25^{\circ} \mathrm{C}$ incubator for 7 days. An initial experiment revealed that the emission of VOCs has achieved the plateau under favorable environments in 7 days. The HbGT6-07 VOCs were obtained in the flask for 20 min at $40{ }^{\circ} \mathrm{C}$ via solid-phase micro-extraction 
(SPME) fiber assemblies (Superco, PA , USA) (Md Kamaruzzaman et al. 2020). The fiber $(2 \mathrm{~cm}, 50 / 30 \mu \mathrm{m}$ divinylbenzene-DVD) was placed straightly into the TRACE ${ }^{\mathrm{TM}}$ GC Ultra (TRACE-DSQ II) (Thermo Electron Corporation, USA) GC intel splitless mode. The desorption time was 5 min and the deported compounds were segregated on a DB-5 MS capillary column $(30 \mathrm{~m} \times 0.25 \mu \mathrm{m} \times 0.25 \mathrm{~mm})$ through the following operating program. Initially, the oven temperature was kept at $50^{\circ} \mathrm{C}$ for $3 \mathrm{~min}$. The column temperatures were slowly raised at $10{ }^{\circ} \mathrm{C} / \mathrm{min}$ from $50^{\circ} \mathrm{C}$ to $180^{\circ} \mathrm{C}$ and increased to $240{ }^{\circ} \mathrm{C}$ at $4{ }^{\circ} \mathrm{C} / \mathrm{min}$, then retained for $5 \mathrm{~min}$. Total running time was $30 \mathrm{~min}$. Helium gas (99.99\%) as used as a carrier with a flow rate of 1.0 $\mathrm{mL} / \mathrm{min}$. The ionising power was set at $70 \mathrm{eV}$ with an acquiring range of 50 to $800 \mathrm{~m} / \mathrm{z}$ and $1 \mathrm{scan} / \mathrm{s}$ scan rate. The temperature of the ion source was $230^{\circ} \mathrm{C}$, and the transfer axis was adjusted at $280^{\circ} \mathrm{C}$. Data acquisition and processing were performed with Thermo Scientific Mass Frontier software system. Based on the comparison of their comparable retention time and their mass spectra, the chemical components were classified with those in the NIST07 database (National Institute of Standard and Technology). Individual peak compositions as a relative percentage of total peak area were recorded. In the meantime, it also obtained and classified the VOCs released from non-inoculated sterilised AWG. Finally, the VOCs appearing in the SPME extract from the non-inoculated PDA were removed during computation.

\section{Statistical analysis}

Data analysis was conducted in the SAS program (SAS ver. 8.0, NC, USA) using the ANOVA technique. Data from different treatments were measured using the $P=0.01$ or 0.05 standard multiple-range test by Duncan. Data linked to independent control with the Student's t-test $(P<0.01$ or 0.05$)$.

\section{Results}

\section{Isolation and screening of isolates HbGT6-07}

A total of 16 Trichoderma isolates were isolated from various agricultural field in a different province of China. The initial screening for effective Trichoderma isolates revealed the percentage of inhibition range at 3 DAI $69.52-81.43 \%$ and at 6 DAl for B. cinerea B05.10 (Supplementary Fig. S3 (A), Table S3). On the other hand, the percentage of inhibition range at 3 DAI $69.52-81.43 \%$ and at 6 DAI for $S$. sclerotiorum A367 (Supplementary Fig. S3 (B), Table S3). Among them, T. asperellum HbGT6-07 potentially reduced the growth of $B$. cinerea B05.10 and S. sclerotiorum A367, respectively. Besides the inhibition of fungal growth, T. asperellum HbGT6-07 suppressed the conidial production of B. cinerea B05.10 and $S$. sclerotiorum A367 in the dual culture assay plates.

\section{Colony morphology and molecular identification of isolates HbGT6-07}

Morphological investigations revealed that the front of the novel isolate HbGT6-07 colony after five days of culture was dark green (colour of spore), and the tail was white (colour of mycelium). The mycelial growth phenotype was rough, and bright green spores started developing at significant levels in the middle of the colonies. Evaluation of the growth and sporulation performance of isolate HbGT6-07 was 
done at ten different solid media. This study showed that PDA, CPA and SDA is the best mycelial growth media to isolate HbGT6-07 (Fig. S4). MM agar media showed minimum growth against the HbGT6-07 isolates. Also, to find out the optimum as well as the best temperature for the growth of the pathogen, the isolate HbGT6-07 was grown at different temperatures on potato dextrose agar medium. After $10 \mathrm{DAl}$, the average mycelial growth, colony diameter, and the number of spores per dish were recorded. From the analysis presented in Supplementary Fig. S5, it can be concluded that the growth of the fungi was better at the temperature range of $20^{\circ} \mathrm{C}, 25^{\circ} \mathrm{C}$ and $30^{\circ} \mathrm{C}$. Maximum average dry weight was observed at $20-30^{\circ} \mathrm{C}$.

Sequencing reactions performed with ITS1/ITS4 primer pairs which amplified the fragments of $-600 \mathrm{bp}$ (Supplementary Fig. S6). Following an evolutionary analysis of the ITS sequences, NCBI BLAST showed that this new strain exhibits the maximum similarity with $T$. asperellum T-17 (KC884774) followed by $T$. hamatum (KC884761), T. koningiopsis (KC884790), T. atroviride (KC884770), T. hatzianum (KC884786), and T. saturnisporum (KC884818), with Protocrea pallida (NR_111329) used as an outgroup (Fig. 1). We identified the strain to be T. asperellum along with the morphological characteristic and called it HbGT607.

\section{The HbGT6-07 CF Influenced the Growth of B. cinereaand S. sclerotiorum}

B. cinereaand $S$. sclerotiorum isolates were cultured on potato dextrose agar (PDA) medleyed with CF of $\mathrm{HbGT6-07,} \mathrm{and} \mathrm{PDA} \mathrm{plus} \mathrm{dd} \mathrm{H}_{2} \mathrm{O}$ was used as the control. In case of $B$. cinerea, the radial colony size on PDA that amended $1 \%(V / V)$ CF were significantly lesser as compared with colonies grown on control treatment. The inhibition percentages of HbGT6-07 CF to $B$. cinerea significantly $(P<0.01)$ increased with an increase in concentration of HbGT6-07 CF (Figure 2, A). Among of the applied concentrations $(10 \%$, $6 \%, 2 \%$, and $1 \%(V / V)$ of $C F, C F$ at a concentration of $10 \%$ showed $93 \%$ growth inhibition to $B$. cinerea, and an inhibition rate of $29 \%$ was recorded when treated with culture filtrate at a concentration of $1 \%$. On the other hand, the \% GI of HbGT6-07 CF to $S$. sclerotiorum significantly $(P<0.01)$ increased with an increase in concentration of HbGT6-07 CF (Figure 2, B). Concentration of $10 \%$ showed $91 \%$ growth inhibition to $S$. sclerotiorum, and an inhibition rate of $17 \%$ was found when treated with $\mathrm{CF}$ at a concentration of $1 \%$.

\section{Efficacy of the VOCs of HbGT6-07 in suppression of B. cinerea and S. sclerotiorum}

The dish within dish method was used to detect the antifungal activity of HbGT6-07 against $B$. cinerea and $S$. sclerotiorum through the production of antifungal volatiles. In the double dish sets of blank AWG/B05.10 and B05/B05 (inner/outer dishes), isolate B05.10 in the external dishes grew and produce sclerotia on PDA with average colony diameters bigger than $14.5 \mathrm{~cm}$ (Fig. 3 A, B). Notably, mycelial growth reduction was observed during the treatments. Initially, all outside B05.10 culture grew normally (average $12 \mathrm{~mm}$ ) up to 4 days but at $5^{\text {th }}$ day HbGT6-07/B05.10 treatment reduced growth rate about 1 mm while AWG and B05.10/B05.10 treatment growth rate 10 and $8 \mathrm{~mm} /$ day, respectively (Fig. $3 \mathrm{C}$ ). B05.10 colonies sclerotia were obtained in the with average sclerotia yields up to 33 and 28 sclerotia per dish, respectively in blank AWG/B05 and B05/B05. In comparison, in the DWD sets of HbGT6-07/B05.10, 
isolate B05.10 grew in the outer plates, but developed limited colonies with an average colony size of 4.1 $\mathrm{cm}$ without apparent sporulation or sclerotia (Fig. 3 D).

The DwD sets of HbGT6-07/A367 demonstrated a related antifungal impact of volatiles from the AWG cultures of HbGT6-07 on mycelial growth and sclerotial development by S. sclerotiorum A367. In the DwD sets of blank AWG/A367 and A367/A367, isolate A367 in the outer plates developed rapidly, colonised the whole outer plates at $20^{\circ} \mathrm{C}$ for $15 \mathrm{~d}$ incubation, and generated sclerotia with yield potential up to 53 and 42 sclerotia per dish. Besides, in the HbGT6-07/A367 DwD sets, isolate A367 in the outer dishes developed gradually, forming modest colonies with an average size of $7.6 \mathrm{~cm}$ after $20^{\circ} \mathrm{C}$ incubation (Fig. 4 A-D).

\section{Biocontrol of disease suppression by $T$. asperellum HbGT6-07}

The findings of the antimicrobial analysis on detached rapeseed leaves indicated that HbGT6-07 hyphal mixtures were successful in suppressing lesion extension responsible by $B$. cinerea and $S$. sclerotiorum (Fig. 5). In the negative control, the hyphal mixtures of HbGT6-07 alone as inoculum, no noticeable exposure or mild infection with development of small leaf lesions ( $<0.5 \mathrm{~mm}$ in size) were recorded on the leaves at $3 \mathrm{~d}$ post-inoculation (dpi) under $20^{\circ} \mathrm{C}$. Furthermore, the serious outbreak was reported on the leaf tissue in the positive control with hyphal components of B05.10 alone as inoculum, and broad necrotic leaf lesions were developed with an average lesion size of up to $23 \mathrm{~mm}$. The hyphal fragments of HbGT6-07 and B05.10 isolates with three biocontrol treatments at the ratios of 33.33:66.67, $50: 50$ and 66.67:33.33 (HbGT6-07: B05.10) as inoculum, the diameter of leaf lesion were reduced by $43 \%, 65 \%$ and $97 \%$, respectively, associated with the treatment of positive control (Fig. 5 left, Supplementary Fig. S7 A).

Equal inhibitory action on rape seed leaves was detected from available hyphal fragments of HbGT6-07 toward invasion with $S$. sclerotiorum A367. While the positive treatment group with the available hyphal mixtures of $A 367$ alone as inoculum responsible for more prominent leaf lesions with $27 \mathrm{~mm}$ of average lesion diameter at $3 \mathrm{dpi}\left(20^{\circ} \mathrm{C}\right)$, the biological control action with viable hyphal fragments of HbGT6-07 and $A 367$ at the ratios of 33.33:66.67, 50:50 and 66.67:33.33 (HbGT6-07:A367) as inoculum caused small leaf lesions with average lesion diameters of 16,9 and $0.6 \mathrm{~mm}$, respectively. The effectiveness of biocontrol strategy of these three treatments was as high as $40 \%, 66 \%$ and $97 \%$ respectively, compared to positive control treatment (Fig. 5 right, Supplementary Fig. S7 B).

\section{Reduction of sclerotia formation under mixed culture condition}

The carrot blocks were the perfect substrates for sclerotia production by $B$. cinerea and S. sclerotiorum. In the mixed culture condition, the number of sclerotia production and the weight of sclerotia were significantly reduced in the co-cultured by the action of Trichoderma isolates HbGT6-07 (Fig. 6 A). Results from this mixed culture assay exhibited that the isolate HbGT6-07 was significantly $(P<0.01)$ reduced the sclerotia production turned into zero as compared to control for B05.10 and A367, respectively (Fig. 6 B). Moreover, the dry weight of sclerotia data also revealed that isolates HbGT6-07 caused complete inhibition of sclerotia production (Fig. 6 C). 


\section{GC/MS profiling of T. asperellum HbGT6-07 VOCs}

The mass spectra structural information of the VOCs was evaluated via the data in the NIST Mass Spectral Search Program (version 2.2). Results of GC-MS analysis identified 32 compounds in the $T$. asperellum $\mathrm{HbGT6-07}$. The molecular weight (MW), name of the compound (NoC), chemical formula (CF), retention time (RT) and relative peak area (RPA) were given in Table 1 and illustrated in Fig. 7. These compounds were into classes of alkane $(\mathrm{R}-\mathrm{H})$, alcohols $(\mathrm{R}-\mathrm{OH})$, aldehydes $(\mathrm{R}-\mathrm{CHO})$, alkene $(\mathrm{R}=)$, amines $\left(\mathrm{R}-\mathrm{NH}_{2}\right)$, benzene $\left(\mathrm{R}-\mathrm{C}_{6} \mathrm{H}_{6}\right)$, and ketone (R-CO) (Fig. 8). 2-Ethylhexanal $\left(\mathrm{C}_{8} \mathrm{H}_{16} \mathrm{O}\right)$ seemed to be the enormous compound with $18.8 \%$ relative peak area (RPA), accompanied by Octan-3-one $\left(\mathrm{C}_{8} \mathrm{H}_{16} \mathrm{O}\right)$ with the RPA value of $11.2 \%$ and Octan-2-one $\left(\mathrm{C}_{8} \mathrm{H}_{16} \mathrm{O}\right)$ with the RPA value of $5.6 \%$. The other 18 molecules, such as 1 -octen-3-ol, were less common, with the RPA levels between $0.9 \%$ to $4.2 \%$.

\section{Discussion}

One of the essential concern of food production is plant disease management. Different combined schemes can be used to breed excellent disease-resistant cultivars, use crop rotation to prevent heavy building up pathogens, change seeds from diseased to disease-free, flexible planting dates, maintain proper moisture in the field, and use pesticides to control plant pathogens. However, the most common method for controlling diseases is the use of pesticides. While a large variety of pests and insects can be targeted by synthetic pesticides, they can cause significant harm to our climate. Overuse of pesticides can seriously affect public health. Thus, use of pesticides to monitor diseases and target precision becomes a major concern.

Some species of the genus Trichoderma are deliberated as potential biological control agents (BCAs), and the modes of action include mycoparasitism, antibiosis, competition, enzyme activity and induced plant defense and active VOCs production (Sood et al. 2020). VOCs derived from microbes can induce the genes responsible for plant defense mechanism and prevent the infections/diseases caused by pathogens (Cordovez et al. 2017). Trichoderma has considerable activity against many pathogenic fungi, e.g. Fusarium a wide range of environmental conditions (Zhang et al. 2014). Moreover, they have been studied extensively for their beneficial role as biofertilizers and in pest management (Gupta et al. 2014). In recent years, role of VOCs as natural BCAs have been studied extensively for many reasons (Conboy et al. 2020; Kaddes et al. 2019; Tahir et al. 2017). Firstly, they offer cost effective methods to control pest by the farmers. Secondly, they reduce the use of chemicals in the agriculture fields. Third, synergistic role of multiple VOCs can target a wide range of pathogens. Fourth, these volatile chemicals promote plant growth and offer high yield. Many microbial VOCs with plant antimicrobial activity (AMA) have been identified in previous studies (Schulz-Bohm et al. 2017; Tilocca et al. 2020). They promote plant growth by protecting from pathogen attack through cost effective and environmentally friendly approach. Although a high number of Trichoderma genera and strains are known to date, the VOC profiles of only a minimal number of fungi have been studied so far (Guo et al. 2019; Quintana-Rodriguez et al. 2018). 
Volatile compounds produced by organisms called Trichoderma have interactions between plants and microorganisms. These spontaneously produced VOCs boost up plant biomass and compete with the growth of infectious pathogens. All microbial VOCs work synergistically as a complex mixture where environmental condition such as nutrient content, composition, humidity, temperature etc. influence the production and mechanism of action (Tilocca et al. 2020). In this study, in order to determine the most successful isolate against B. cinerea B05.10 and S. sclerotiorum A367, we isolated sixteen Trichoderma strains collected from rhizosphere soil. Isolate HbGT6-07 significantly reduced the radial growth of the microbes and was capable of entirely overgrowing mycelia of plant microbes. ITS rDNA region was amplified with specific primers ITS1 and ITS4. The primers provided amplified products with a size of $-600 \mathrm{bp}$. This finding is in accordance with many researchers who effectively achieved a $-600 \mathrm{bp}$ segment in Trichoderma after amplification of the 5.8-rDNA region (Castrillo et al. 2016; Chakraborty et al. 2010). The results acquired from BLAST query sites allowed us to identify with at least $99 \%$ homology the various species-level isolates. The result generated from the evolutionary analysis is compatible with earlier inquiries concerning the topology of Trichoderma phylogeny (Filizola et al. 2019).

As potential biocontrol agents that can reduce the effects of multiple plant diseases, VOCs have recently been proposed (Baiyee et al. 2019; Wonglom et al. 2019) (Blom et al. 2011; Cortes Barco et al. 2010). The volatile antifungal molecules found in a conidial suspension from Trichoderma isolate HbGT6-07 are groups of the following chemical components, alcohols, aldehyde, ketone, alkane, alkene, amines, benzene. 2-Ethylhexanal $\left(\mathrm{C}_{8} \mathrm{H}_{16} \mathrm{O}\right)$ from the aldehyde group were contribute the highest antifungal activity (4.89\%) (Wonglom et al. 2020). Octan-2-one and Octan-3-one are in a ketone displayed in the VOCs by about 3.05\% (Table 1), having different antimicrobial potential such as antifungal efficacy (Fernando et al. 2005). Though fatty acids are less efficient than certain substances and chemical fungicides, antimicrobial activity has been reported (Pohl et al. 2011). In agriculture, microbial VOCs were used to fumigate foodstuffs and regulate microorganisms throughout plants. Nonetheless, single VOCs have declined to have an adverse impact in several of these experiments, while blends have been successful in mediating stimulation of plant growth and development (R. Hung et al. 2015; Naznin et al. 2013).

VOCs from microbial species have shown to be able to induce protective reactions against microbial infection and to cause systemic resistance (Naznin et al. 2014). For example, compounds such as 6amyl-a-pyrone, 1-octen-3-ol, methyl benzoate and m-cresol induce systemic pathogen tolerance by disrupting the signalling pathways for salicylic and jasmonic acid (Naznin et al. 2013; Vinale et al. 2008). Consequently, limited information is available about plant genes in acting to VOCs released by pathogens (Naznin et al. 2013; Vinale et al. 2008). Earlier research suggested that plants revealed to the volatile stage of limonene, 3-methylbutanal and undecane induced substantial effects on plant diameter and chlorophyll contents (R. Hung et al. 2015) and we found that our isolate released 3-Methylbutan-1-ol, 2Methylbutanol, limonene, camphor, $\beta$-cedrene and a-bergamotene, called as natural volatiles microbial (Fiedler et al. 2001; Jeleń et al. 2014). Although these molecules have been reported to be ubiquitous, however, they are not expected to be the factor of our obtained growth stimulation. Though low concentration of 2-Ethylhexanal promotes the growth of Arabidopsis, high concentration lessens plant 
growth (Blom et al. 2011; Splivallo et al. 2007). Our studied isolate HbGT6-07 also produced 2Ethylhexanal.

In this study, we found that the Trichoderma isolate HbGT6-07 effectively suppressed sporulation of $B$. cinerea B05.10 and S. sclerotiorum A367 on leaves of rapeseed. Recent evidence suggested that $C$. rosea simultaneously suppresses the B. cinerea sporulation via mycoparasitism (Moraga-Suazo et al. 2011). Throughout this study, these two approaches can appear in the inhibition of $B$. cinerea B05.10, and $S$. sclerotiorum A367 sporulation by Trichoderma HbGT6-07 isolates, as it can actively penetrate the $B$. cinerea B05.10 and S. sclerotiorum A367 colonies in dual culture methods. Trichoderma isolates HbGT607 substantially improved the rapeseed vigour index as linked to the control group. Also, they demonstrated both growth-enhancing and immunity-inducing impact on rape seedlings. The experimental data of this study revealed that the targeted Trichoderma isolate HbGT6-07 can enhance the production of adjacent plants by releasing several plant VOCs which boost the resistance response (Blande et al. 2014). However, according to our results, we are suggesting in details research on natural biocontrol agent like Trichoderma to turn on plant defense system to avoid the action of pathogens.

\section{Conclusion}

Trichoderma was identified as a globally recognized biocontrol fungus due to its effective and broadspectrum of antimicrobial actions. This study provides empirical evidence that VOCs released by Trichoderma isolates HbGT6-07 have an inhibitory effect and may be used as an effective alternative option of synthetic fungicides to prevent various fungal pathogens growth. Besides, Trichoderma isolate HbGT6-07 cultural filtrates are known to become the most useful and efficient agents for regulating a broad range of microorganisms like $B$. cinerea and $S$. Sclerotiorum. Finally, the upsurge in VOCs from Trichoderma isolate HbGT6-07 may be attributed to changes in gene expression so that the VOCs effect assessment would be the focus of further study in vivo assays and genetic analysis.

\section{Declarations}

Supplementary Materials The Supplementary Material for this article can be found online.

Author contributions Md. Kamaruzzaman conceived and designed the experiments. Md. Kamaruzzaman and Md. Samiul Islam performed the experiments. Md. Kamaruzzaman and Md. Samiul Islam analyzed the data. Md. Kamaruzzaman and Md. Samiul Islam, Shakil Ahmed Polash and Razia Sultana contributed formal analysis. Md. Kamaruzzaman and Md. Samiul Islam, and Shakil Ahmed Polash wrote the manuscript with input from all co-authors. All authors read and approved the final manuscript.

Funding The authors did not receive any financial grand.

Competing Interests The authors declare no conflict of interest.

\section{References}


Batta, Y. A. (2004). Effect of treatment with Trichoderma harzianum Rifai formulated in invert emulsion on postharvest decay of apple blue mold. International journal of food microbiology, 96(3), 281-288.

Begum, M. F., Rahman, M. A., \& Alam, M. F. (2010). Biological control of Alternaria fruit rot of chili by Trichoderma species under field conditions. Mycobiology, 38(2), 113-117.

Benítez, T., Rincón, A. M., Limón, M. C., \& Codon, A. C. (2004). Biocontrol mechanisms of Trichoderma strains. International microbiology, 7(4), 249-260.

Bitas, V., Kim, H.-S., Bennett, J. W., \& Kang, S. (2013). Sniffing on microbes: diverse roles of microbial volatile organic compounds in plant health. Molecular Plant-Microbe Interactions, 26(8), 835-843.

Blande, J. D., Holopainen, J. K., \& Niinemets, Ü. (2014). Plant volatiles in polluted atmospheres: stress responses and signal degradation. Plant, cell \& environment, 37(8), 1892-1904.

Blaszczyk, L., Siwulski, M., Sobieralski, K., Lisiecka, J., \& Jedryczka, M. (2014). Trichoderma spp.application and prospects for use in organic farming and industry. Journal of plant protection research, $54(4)$.

Blom, D., Fabbri, C., Connor, E. C., Schiestl, F. P., Klauser, D. R., Boller, T., et al. (2011). Production of plant growth modulating volatiles is widespread among rhizosphere bacteria and strongly depends on culture conditions. Environmental microbiology, 13(11), 3047-3058.

Büttner, P., Koch, F., Voigt, K., Quidde, T., Risch, S., Blaich, R., et al. (1994). Variations in ploidy among isolates of Botrytis cinerea: implications for genetic and molecular analyses. Current Genetics, 25(5), 445-450. https://doi.org/10.1007/BF00351784

Castrillo, M. L., Bich, G. A., Zapata, P. D., \& Villalba, L. (2016). Biocontrol of Leucoagaricus gongylophorus of leaf-cutting ants with the mycoparasitic agent Trichoderma koningiopsis.

Chakraborty, B. N., Chakraborty, U., Saha, A., Dey, P. L., \& Sunar, K. (2010). Molecular characterization of Trichoderma viride and Trichoderma harzianum isolated from soils of North Bengal based on rDNA markers and analysis of their PCR-RAPD profiles. Global Journal of Biotechnology \& Biochemistry, 5(1), $55-61$.

Chowdappa, P., Kumar, S. P. M., Lakshmi, M. J., \& Upreti, K. K. (2013). Growth stimulation and induction of systemic resistance in tomato against early and late blight by Bacillus subtilis OTPB1 or Trichoderma harzianum OTPB3. Biological control, 65(1), 109-117.

Conboy, N. J. A., McDaniel, T., George, D., Ormerod, A., Edwards, M., Donohoe, P., et al. (2020). Volatile Organic Compounds as Insect Repellents and Plant Elicitors: an Integrated Pest Management (IPM) Strategy for Glasshouse Whitefly (Trialeurodes vaporariorum). Journal of chemical ecology, 46(11), 1090-1104. 
Cordovez, V., Mommer, L., Moisan, K., Lucas-Barbosa, D., Pierik, R., Mumm, R., et al. (2017). Plant phenotypic and transcriptional changes induced by volatiles from the fungal root pathogen Rhizoctonia solani. Frontiers in plant science, 8, 1262.

Cortes-Barco, A. M., Goodwin, P. H., \& Hsiang, T. (2010). Comparison of induced resistance activated by benzothiadiazole,(2R, 3R)-butanediol and an isoparaffin mixture against anthracnose of Nicotiana benthamiana. Plant Pathology, 59(4), 643-653.

Crespo, E., Hordijk, C. A., de Graaf, R. M., Samudrala, D., Cristescu, S. M., Harren, F. J. M., \& van Dam, N. M. (2012). On-line detection of root-induced volatiles in Brassica nigra plants infested with Delia radicum L. root fly larvae. Phytochemistry, 84, 68-77.

de los Santos-Villalobos, S., Guzmán-Ortiz, D. A., Gómez-Lim, M. A., Délano-Frier, J. P., de-Folter, S., Sánchez-García, P., \& Peña-Cabriales, J. J. (2013). Potential use of Trichoderma asperellum (Samuels, Liechfeldt et Nirenberg) T8a as a biological control agent against anthracnose in mango (Mangifera indica L.). Biological Control, 64(1), 37-44.

Degenkolb, T., Von Doehren, H., Fog Nielsen, K., Samuels, G. J., \& Brückner, H. (2008). Recent advances and future prospects in peptaibiotics, hydrophobin, and mycotoxin research, and their importance for chemotaxonomy of Trichoderma and Hypocrea. Chemistry \& Biodiversity, 5(5), 671-680.

Elad, Y., Gullino, M. L., Shtienberg, D., \& Aloi, C. (1995). Managing Botrytis cinerea on tomatoes in greenhouses in the Mediterranean. Crop Protection, 14(2), 105-109.

Fernando, W. G. D., Ramarathnam, R., Krishnamoorthy, A. S., \& Savchuk, S. C. (2005). Identification and use of potential bacterial organic antifungal volatiles in biocontrol. Soil Biology and Biochemistry, 37(5), 955-964.

Fiedler, K., Schütz, E., \& Geh, S. (2001). Detection of microbial volatile organic compounds (MVOCs) produced by moulds on various materials. International Journal of Hygiene and Environmental Health, 204(2-3), 111-121.

Filizola, P. R. B., Luna, M. A. C., de Souza, A. F., Coelho, I. L., Laranjeira, D., \& Campos-Takaki, G. M. (2019). Biodiversity and phylogeny of novel Trichoderma isolates from mangrove sediments and potential of biocontrol against Fusarium strains. Microbial Cell Factories, 18(1), 89.

Fontenelle, A. D. B., Guzzo, S. D., Lucon, C. M. M., \& Harakava, R. (2011). Growth promotion and induction of resistance in tomato plant against Xanthomonas euvesicatoria and Alternaria solani by Trichoderma spp. Crop Protection, 30(11), 1492-1500.

Geraldine, A. M., Lopes, F. A. C., Carvalho, D. D. C., Barbosa, E. T., Rodrigues, A. R., Brandão, R. S., et al. (2013). Cell wall-degrading enzymes and parasitism of sclerotia are key factors on field biocontrol of white mold by Trichoderma spp. Biological Control, 67(3), 308-316. 
Glare, T., Caradus, J., Gelernter, W., Jackson, T., Keyhani, N., Köhl, J., et al. (2012). Have biopesticides come of age? Trends in biotechnology, 30(5), 250-258.

Guo, Y., Ghirardo, A., Weber, B., Schnitzler, J.-P., Benz, J. P., \& Rosenkranz, M. (2019). Trichoderma species differ in their volatile profiles and in antagonism toward ectomycorrhiza Laccaria bicolor. Frontiers in microbiology, 10, 891.

Gupta, V. G., Schmoll, M., Herrera-Estrella, A., Upadhyay, R. S., Druzhinina, I., \& Tuohy, M. (2014). Biotechnology and biology of Trichoderma. Newnes.

Hao, Q., Deng, J., Yang, F., Wang, G., Xiao, Y., \& Xiao, X. (2020). Biological Control of Tomato Gray Mold Caused by Botrytis Cinerea with the Entomopathogenic Fungus Metarhizium Anisopliae. Pathogens, 9(3), 213.

Harman, G. E. (2006). Overview of mechanisms and uses of Trichoderma spp. Phytopathology, 96(2), 190-194.

Heydari, A., \& Pessarakli, M. (2010). A review on biological control of fungal plant pathogens using microbial antagonists. Journal of biological sciences, 10(4), 273-290.

Horst, L. E., Locke, J., Krause, C. R., McMahon, R. W., Madden, L. V, \& Hoitink, H. A. J. (2005). Suppression of Botrytis blight of Begonia by Trichoderma hamatum 382 in peat and compost-amended potting mixes. Plant disease, 89(11), 1195-1200.

Hung, D. T., Protter, A. A., Chakravarty, S., \& Jain, R. P. (2015, May 19). Bridged heterocyclic compounds and methods of use. Google Patents.

Hung, R., Lee, S., \& Bennett, J. W. (2013). Arabidopsis thaliana as a model system for testing the effect of Trichoderma volatile organic compounds. Fungal ecology, 6(1), 19-26.

Hung, R., Lee, S., \& Bennett, J. W. (2015). Fungal volatile organic compounds and their role in ecosystems. Applied Microbiology and Biotechnology, 99(8), 3395-3405.

Jain, A., Singh, A., Singh, S., \& Singh, H. B. (2015). Biological management of Sclerotinia sclerotiorum in pea using plant growth promoting microbial consortium. Journal of basic microbiology, 55(8), 961-972.

Jeleń, H., Błaszczyk, L., Chełkowski, J., Rogowicz, K., \& Strakowska, J. (2014). Formation of 6-n-pentyl-2Hpyran-2-one (6-PAP) and other volatiles by different Trichoderma species. Mycological Progress, 13(3), $589-600$.

Kaddes, A., Fauconnier, M.-L., Sassi, K., Nasraoui, B., \& Jijakli, M.-H. (2019). Endophytic fungal volatile compounds as solution for sustainable agriculture. Molecules, 24(6), 1065. 
Kai, M., Effmert, U., Berg, G., \& Piechulla, B. (2007). Volatiles of bacterial antagonists inhibit mycelial growth of the plant pathogen Rhizoctonia solani. Archives of microbiology, 187(5), 351-360.

Kamaruzzaman, M., Hao, F., Wu, M., \& Li, G. (2018). Gray mold of strawberry (Fragaria ananassa) caused by a rare pink-colored isolate of Botrytis cinerea in China. Australasian Plant Pathology, 47(6), 587-589.

Kamaruzzaman, M., Lyu, A., Zhang, J., Wu, M., Yang, L., Chen, W., \& Li, G. (2020). Competitive saprophytic ability of the hypovirulent isolate QT5-19 of Botrytis cinerea and its importance in biocontrol of necrotrophic fungal pathogens. Biological Control, 142, 104182.

Korpi, A., Järnberg, J., \& Pasanen, A.-L. (2009). Microbial volatile organic compounds. Critical reviews in toxicology, 39(2), 139-193.

Kovach, J., Petzoldt, R., \& Harman, G. E. (2000). Use of honey bees and bumble bees to disseminate Trichoderma harzianum 1295-22 to strawberries for Botrytis control. Biological Control, 18(3), 235-242.

Lee, S., Yap, M., Behringer, G., Hung, R., \& Bennett, J. W. (2016). Volatile organic compounds emitted by Trichoderma species mediate plant growth. Fungal Biology and Biotechnology, 3(1), 7.

Lopes, F. A. C., Steindorff, A. S., Geraldine, A. M., Brandão, R. S., Monteiro, V. N., Júnior, M. L., et al. (2012). Biochemical and metabolic profiles of Trichoderma strains isolated from common bean crops in the Brazilian Cerrado, and potential antagonism against Sclerotinia sclerotiorum. Fungal Biology, 116(7), 815-824.

Magioli, C., \& Mansur, E. (2005). Eggplant (Solanum melongena L.): tissue culture, genetic transformation and use as an alternative model plant. Acta Botanica Brasilica, 19(1), 139-148.

McNeal, K. S., \& Herbert, B. E. (2009). Volatile organic metabolites as indicators of soil microbial activity and community composition shifts. Soil Science Society of America Journal, 73(2), 579-588.

Menjivar, R. D., Cabrera, J. A., Kranz, J., \& Sikora, R. A. (2012). Induction of metabolite organic compounds by mutualistic endophytic fungi to reduce the greenhouse whitefly Trialeurodes vaporariorum (Westwood) infection on tomato. Plant and soil, 352(1-2), 233-241.

Moraga-Suazo, P., Opazo, A., Zaldúa, S., González, G., \& Sanfuentes, E. (2011). Evaluation of Trichoderma spp. and Clonostachys spp. strains to control Fusarium circinatum in Pinus radiata seedlings. Chilean journal of agricultural research, 71(3), 412.

Müller, A., Faubert, P., Hagen, M., zu Castell, W., Polle, A., Schnitzler, J.-P., \& Rosenkranz, M. (2013). Volatile profiles of fungi-chemotyping of species and ecological functions. Fungal Genetics and Biology, 54, 2533.

Naznin, H. A., Kimura, M., Miyazawa, M., \& Hyakumachi, M. (2013). Analysis of volatile organic compounds emitted by plant growth-promoting fungus Phoma sp. GS8-3 for growth promotion effects on 
tobacco. Microbes and environments, 28(1), 42-49.

Naznin, H. A., Kiyohara, D., Kimura, M., Miyazawa, M., Shimizu, M., \& Hyakumachi, M. (2014). Systemic resistance induced by volatile organic compounds emitted by plant growth-promoting fungi in Arabidopsis thaliana. PLoS One, 9(1), e86882.

Nieto-Jacobo, M. F., Steyaert, J. M., Salazar-Badillo, F. B., Nguyen, D. V., Rostás, M., Braithwaite, M., et al. (2017). Environmental growth conditions of Trichoderma spp. affects indole acetic acid derivatives, volatile organic compounds, and plant growth promotion. Frontiers in plant science, 8, 102.

Ownley, B. H., Gwinn, K. D., \& Vega, F. E. (2010). Endophytic fungal entomopathogens with activity against plant pathogens: ecology and evolution. BioControl, 55(1), 113-128.

Peñuelas, J., Asensio, D., Tholl, D., Wenke, K., Rosenkranz, M., Piechulla, B., \& Schnitzler, J. P. (2014). Biogenic volatile emissions from the soil. Plant, cell \& environment, 37(8), 1866-1891.

Pohl, C. H., Kock, J. L. F., \& Thibane, V. S. (2011). Antifungal free fatty acids: a review. Science against microbial pathogens: communicating current research and technological advances, 3, 61-71.

Quintana-Rodriguez, E., Rivera-Macias, L. E., Adame-Alvarez, R. M., Torres, J. M., \& Heil, M. (2018). Shared weapons in fungus-fungus and fungus-plant interactions? Volatile organic compounds of plant or fungal origin exert direct antifungal activity in vitro. Fungal Ecology, 33, 115-121.

Raeder, U., \& Broda, P. (1985). Rapid preparation of DNA from filamentous fungi. Letters in Applied Microbiology, 1(1), 17-20. https://doi.org/10.1111/j.1472-765X.1985.tb01479.x

Rahnama, K. (2016). Identification of volatile organic compounds of Trichoderma spp. using static headspace gas chromatography-mass spectrometry.

Rigamonte, T. A., Pylro, V. S., \& Duarte, G. F. (2010). The role of mycorrhization helper bacteria in the establishment and action of ectomycorrhizae associations. Brazilian Journal of Microbiology, 41(4), 832-840.

Samuels, G. J., Dodd, S. L., Gams, W., Castlebury, L. A., \& Petrini, O. (2002). Trichoderma species associated with the green mold epidemic of commercially grown Agaricus bisporus. Mycologia, 94(1), $146-170$.

Schalchli, H., Tortella, G. R., Rubilar, O., Parra, L., Hormazabal, E., \& Quiroz, A. (2016). Fungal volatiles: an environmentally friendly tool to control pathogenic microorganisms in plants. Critical reviews in biotechnology, 36(1), 144-152.

Schenkel, D., Lemfack, M. C., Piechulla, B., \& Splivallo, R. (2015). A meta-analysis approach for assessing the diversity and specificity of belowground root and microbial volatiles. Frontiers in plant science, 6, 707. 
Schulz-Bohm, K., Martín-Sánchez, L., \& Garbeva, P. (2017). Microbial volatiles: small molecules with an important role in intra-and inter-kingdom interactions. Frontiers in microbiology, 8, 2484.

Schuster, A., \& Schmoll, M. (2010). Biology and biotechnology of Trichoderma. Applied microbiology and biotechnology, 87(3), 787-799.

Segarra, G., Casanova, E., Avilés, M., \& Trillas, I. (2010). Trichoderma asperellum strain T34 controls Fusarium wilt disease in tomato plants in soilless culture through competition for iron. Microbial ecology, 59(1), 141-149.

Siddiquee, S., Cheong, B. E., Taslima, K., Kausar, H., \& Hasan, M. M. (2012). Separation and identification of volatile compounds from liquid cultures of Trichoderma harzianum by GC-MS using three different capillary columns. Journal of chromatographic science, 50(4), 358-367.

Singh, R. K., Kumar, P., Tiwari, N. N., Singh, S. P., Tiwari, A. K., Vishwakarma, S. K., et al. (2014). Role of Endochitinase Gene and Efficacy of Trichoderma Against Colletotrichumfalcatum Went. Causing Red Rot Disease in Sugarcane. Sugar Tech, 16(2), 180-188.

Sood, M., Kapoor, D., Kumar, V., Sheteiwy, M. S., Ramakrishnan, M., Landi, M., et al. (2020). Trichoderma: The "secrets" of a multitalented biocontrol agent. Plants, 9(6), 762.

Suwannarach, N., Kumla, J., Bussaban, B., Nuangmek, W., Matsui, K., \& Lumyong, S. (2013).

Biofumigation with the endophytic fungus Nodulisporium spp. CMU-UPE34 to control postharvest decay of citrus fruit. Crop protection, 45, 63-70.

Tahir, H. A. S., Gu, Q., Wu, H., Raza, W., Hanif, A., Wu, L., et al. (2017). Plant growth promotion by volatile organic compounds produced by Bacillus subtilis SYST2. Frontiers in Microbiology, 8, 171.

Tilocca, B., Cao, A., \& Migheli, Q. (2020). Scent of a Killer: microbial volatilome and its role in the biological control of plant pathogens. Frontiers in Microbiology, 11.

Vinale, F., Sivasithamparam, K., Ghisalberti, E. L., Marra, R., Woo, S. L., \& Lorito, M. (2008). Trichodermaplant-pathogen interactions. Soil Biology and Biochemistry, 4O(1), 1-10.

Vos, C. M., Yang, Y., De Coninck, B., \& Cammue, B. P. A. (2014). Fungal (-like) biocontrol organisms in tomato disease control. Biological control, 74, 65-81.

Weindling, R. (1932). Trichoderma lignorum as a parasite of other soil fungi. Phytopathology, 22(8), 837845 .

Wonglom, P., Daengsuwan, W., Ito, S., \& Sunpapao, A. (2019). Biological control of Sclerotium fruit rot of snake fruit and stem rot of lettuce by Trichoderma sp. T76-12/2 and the mechanisms involved.

Physiological and Molecular Plant Pathology, 107, 1-7. 
Wonglom, P., Ito, S., \& Sunpapao, A. (2020). Volatile organic compounds emitted from endophytic fungus Trichoderma asperellum T1 mediate antifungal activity, defense response and promote plant growth in lettuce (Lactuca sativa). Fungal Ecology, 43, 100867.

Wu, Q., Sun, R., Ni, M., Yu, J., Li, Y., Yu, C., et al. (2017). Identification of a novel fungus, Trichoderma asperellum GDFS1009, and comprehensive evaluation of its biocontrol efficacy. PloS one, 12(6), e0179957.

You, J., Zhang, J., Wu, M., Yang, L., Chen, W., \& Li, G. (2016). Multiple criteria-based screening of Trichoderma isolates for biological control of Botrytis cinerea on tomato. Biological control, 101, 31-38.

Zhang, F., Yang, X., Ran, W., \& Shen, Q. (2014). Fusarium oxysporum induces the production of proteins and volatile organic compounds by Trichoderma harzianum T-E5. FEMS Microbiology Letters, 359(1), 116-123.

\section{Table}

Table 1. HS-SPME/gas chromatography-mass spectrometry (GC-MS) profile of volatile organic compounds (VOCs) produced by T. asperellum HbGT6-07 


\begin{tabular}{|c|c|c|c|c|}
\hline$\overline{\mathrm{SL}} \mathrm{RT}$ & Compound Name and molecular formula (MF & lar weigh & k Area (\%) & CAS No. \\
\hline 16.67 & Ethanol $\left(\mathrm{C}_{2} \mathrm{H}_{6} \mathrm{O}\right)$ & 46.07 & 1.3 & $64-17-5$ \\
\hline 27.53 & Propan-2-one $\left(\mathrm{C}_{3} \mathrm{H}_{8} \mathrm{O}\right)$ & 60.10 & 1.5 & $67-64-1$ \\
\hline 38.59 & Butane-2,3-dione $\left(\mathrm{C}_{4} \mathrm{H}_{8} \mathrm{O}\right)$ & 86.08 & 1.1 & $431-03-8$ \\
\hline 49.23 & Acetic acid $\left(\mathrm{C}_{2} \mathrm{H}_{4} \mathrm{O}_{2}\right)$ & 60.05 & 1.6 & $64-19-7$ \\
\hline 510.26 & 3-Methylbutanol $\left(\mathrm{C}_{5} \mathrm{H}_{10} \mathrm{O}\right)$ & 86.13 & 1.8 & $590-86-3$ \\
\hline 611.17 & 2-Methylbutanol $\left(\mathrm{C}_{5} \mathrm{H}_{10} \mathrm{O}\right)$ & 86.13 & 2.1 & $96-17-3$ \\
\hline 712.30 & 3-Methylbutan-1-ol $\left(\mathrm{C}_{5} \mathrm{H}_{12} \mathrm{O}\right)$ & 88.14 & 0.9 & $123-51-3$ \\
\hline 812.72 & 2-Methylpropanoic acid $\left(\mathrm{C}_{4} \mathrm{H}_{8} \mathrm{O}_{2}\right)$ & 88.10 & 1.6 & 79-31-2 \\
\hline 913.33 & Butanoic acid $\left(\mathrm{C}_{4} \mathrm{H}_{8} \mathrm{O}_{2}\right)$ & 88.10 & 2.4 & $107-92-6$ \\
\hline 1013.99 & 2-Ethylhexanal $\left(\mathrm{C}_{8} \mathrm{H}_{16} \mathrm{O}\right)$ & 128.21 & 18.8 & $123-05-7$ \\
\hline 1114.63 & 3-Methylbutanoic acid $\left(\mathrm{C}_{5} \mathrm{H}_{10} \mathrm{O}_{2}\right)$ & 102.13 & 4.2 & $503-74-2$ \\
\hline 1215.26 & Ethylbenzene $\left(\mathrm{C}_{8} \mathrm{H}_{10}\right)$ & 106.16 & 1.5 & $100-41-4$ \\
\hline 1315.44 & Xylene $\left(\mathrm{C}_{8} \mathrm{H}_{10}\right)$ & 106.16 & 2.4 & $1330-20-7$ \\
\hline 1416.08 & Heptan-2-one $\left(\mathrm{C}_{7} \mathrm{H}_{14} \mathrm{O}\right)$ & 114.18 & 1.6 & $110-43-0$ \\
\hline 1516.52 & Styrene $\left(\mathrm{C}_{8} \mathrm{H}_{8}\right)$ & 104.14 & 1.5 & $100-42-5$ \\
\hline 1616.72 & Heptanal $\left(\mathrm{C}_{7} \mathrm{H}_{14} \mathrm{O}\right)$ & 114.18 & 1.9 & $111-71-7$ \\
\hline 1717.62 & Octan-2-one $\left(\mathrm{C}_{8} \mathrm{H}_{16} \mathrm{O}\right)$ & 128.21 & 5.6 & $111-13-7$ \\
\hline 1818.14 & Octan-3-one $\left(\mathrm{C}_{8} \mathrm{H}_{16} \mathrm{O}\right)$ & 128.21 & 11.2 & $106-68-3$ \\
\hline 1918.72 & Octanal $\left(\mathrm{C}_{8} \mathrm{H}_{16} \mathrm{O}\right)$ & 128.21 & 1.1 & $124-13-0$ \\
\hline 2019.00 & 2-Ethylhexan-1-ol $\left(\mathrm{C}_{8} \mathrm{H}_{18} \mathrm{O}\right)$ & 130.22 & 2.8 & $104-76-7$ \\
\hline 2119.28 & Limonene $\left(\mathrm{C}_{10} \mathrm{H}_{16}\right)$ & 136.23 & 0.9 & $138-86-3$ \\
\hline 2220.36 & Undecane $\left(\mathrm{C}_{11} \mathrm{H}_{24}\right)$ & 156.30 & 1.3 & $1120-21-4$ \\
\hline 2322.14 & Camphor $\left(\mathrm{C}_{10} \mathrm{H}_{16} \mathrm{O}\right)$ & 152.23 & 0.9 & $21368-68-3$ \\
\hline 2422.35 & Decanal $\left(\mathrm{C}_{10} \mathrm{H}_{20} \mathrm{O}\right)$ & 156.26 & 1.7 & $112-31-2$ \\
\hline 2523.34 & Undecan-2-one $\left(\mathrm{C}_{11} \mathrm{H}_{22} \mathrm{O}\right)$ & 170.29 & 5.8 & $112-12-9$ \\
\hline 2623.80 & Undecanal $\left(\mathrm{C}_{11} \mathrm{H}_{22} \mathrm{O}\right)$ & 170.29 & 1.1 & $112-44-7$ \\
\hline 2724.48 & $\beta$-Cedrene $\left(\mathrm{C}_{15} \mathrm{H}_{24}\right)$ & 204.35 & 1.0 & $546-28-1$ \\
\hline 2825.40 & Octadecane $\left(\mathrm{C}_{18} \mathrm{H}_{38}\right)$ & 254.49 & 1.9 & $593-45-3$ \\
\hline 2925.98 & $\alpha$-Bergamotene $\left(\mathrm{C}_{15} \mathrm{H}_{24}\right)$ & 204.35 & 1.4 & $17699-05-7$ \\
\hline 3026.84 & 2,6-Ditert-butyl-4-methylphenol $\left(\mathrm{C}_{15} \mathrm{H}_{24} \mathrm{O}\right)$ & 220.35 & 1.7 & $128-37-0$ \\
\hline 3127.85 & Heptadecane $\left(\mathrm{C}_{17} \mathrm{H}_{36}\right)$ & 240.46 & 0.9 & $629-78-7$ \\
\hline 3228.74 & 6-Pentylpyran-2-one $\left(\mathrm{C}_{10} \mathrm{H}_{14} \mathrm{O}_{2}\right)$ & 166.22 & 2.3 & 27593-23-3 \\
\hline
\end{tabular}

$R T^{1}=$ Retention Time; $M F^{2}=$ Molecular Formula; $M W^{3}=$ Molecular Weight (Da); $R P A^{4}=$ Relative Peck Area; $C A S N r^{6}=$ Chemical Abstracts Service number. The VOCs of T. asperellum HbGT6-07 with the RPAs less than or equal $0.85 \%$ were not included.

\section{Supplemental Legends}

Fig. S1 a In-vitro efficacy of T. asperellum HbGT6-07 isolates against B. cinerea (B05.10) and bS. sclerotiorum (A367) after 3 and 6 days-after-inoculation (DAl)

Fig. S2 PCR amplification of T. asperellum HbGT6-07 isolates were amplified the fragments with ITS1/ITS4 primer pairs in -600 bp region 
Fig. S3 Diagram of detection of antifungal activity through the production of volatile organic compounds using dish within dish method (DwD)

Fig. S4 Hyphal fragments preparation outlines at different treatment ratios (33.33:66.67, 50:50 and 66.67:33.33)

Fig. S5 The reduction of lesion diameter by the isolates of $T$. asperellum HbGT6-07 against B05.10and A367 fungal infection. a The formation of necrotic lesions ( $<0.5 \mathrm{~mm}$ in size) by B05.10 isolates was reduced by the isolates HbGT6-07 after 3 dpi while b A367 causing lesion diameter was suppressed significantly at $3 \mathrm{dpi}$.

Table S1 Trichoderma strains screened for superior antifungal VOCs production.

Table S2 The list of species and GenBank accession numbers of DNA sequences for constructing phylogenetic tree.

Table S3 Primary screening of Trichoderma species against B. cinerea and S. sclerotiorum by dual culture.

\section{Figures}

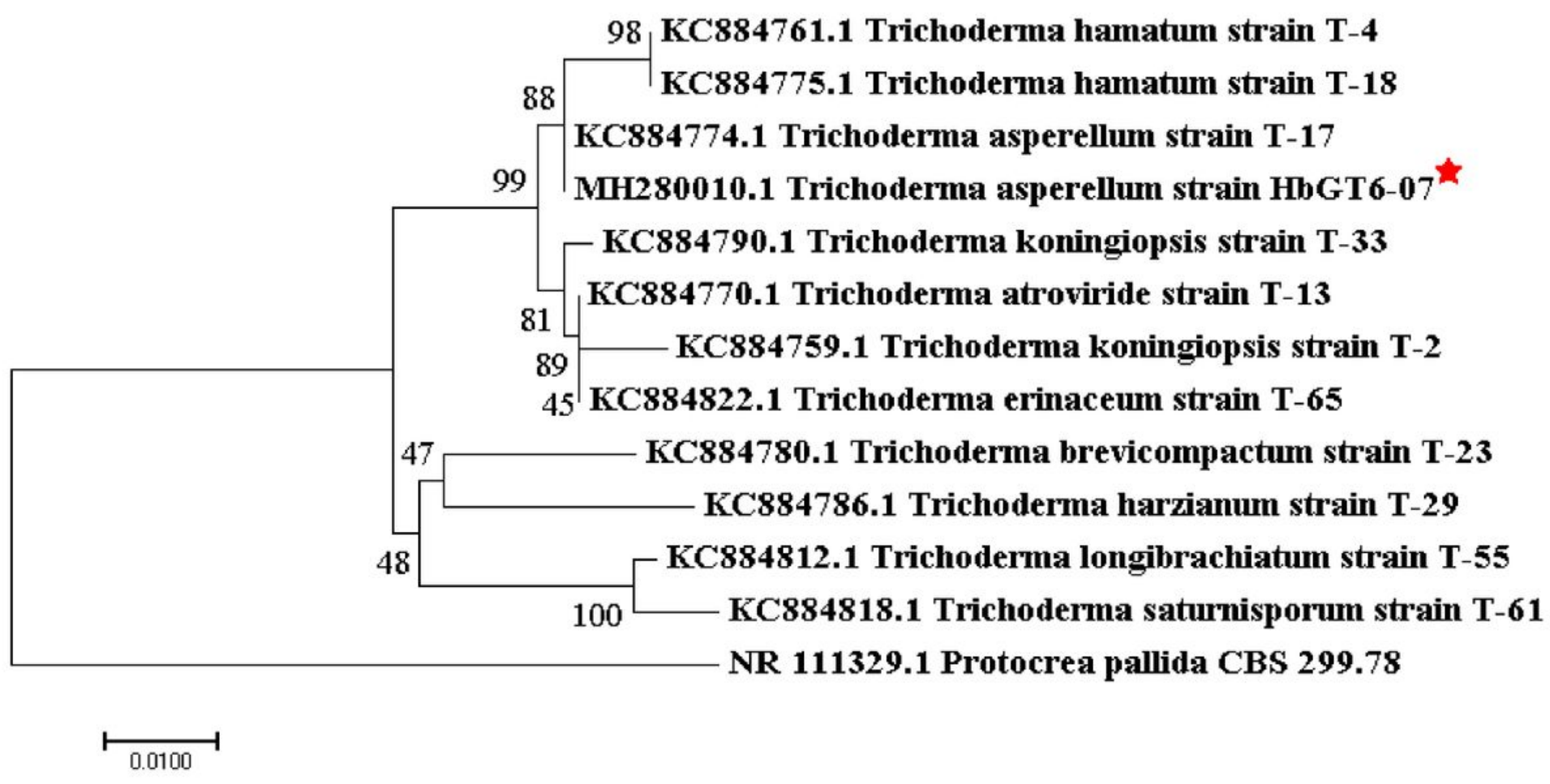

Figure 1

Phylogenetic tree depending on the ITS region of the genomic rDNA gene of 2 isolates and 11 representative strains of Trichoderma. The Neighbor-Joining ( $N J$ ) method was done through MEGA7 
where bootstrap values $(n=1000)$ higher than $50 \%$ are visible at the internodes in the tree. As the outer group, Protocrea pallida CBS299.78 strain was used

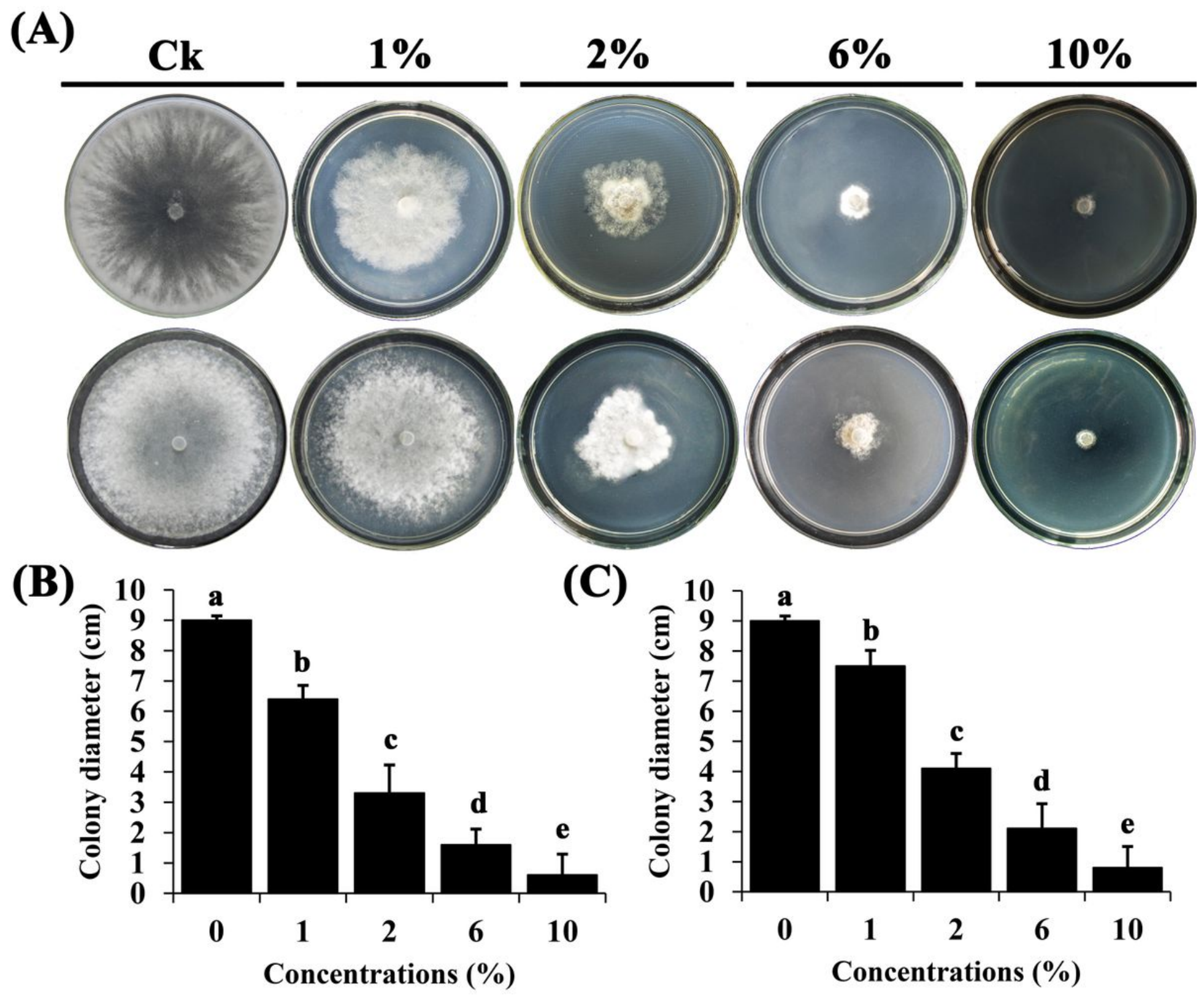

Figure 2

$(a, b)$ Inhibition percentages of HbGT6-07 CF to B. cinerea and $(a, c)$ HbGT6-07 CF to S. sclerotiorum 
(A)

\section{Ck (AWG) AWG+HbGT6-07 AWG+B05.10}

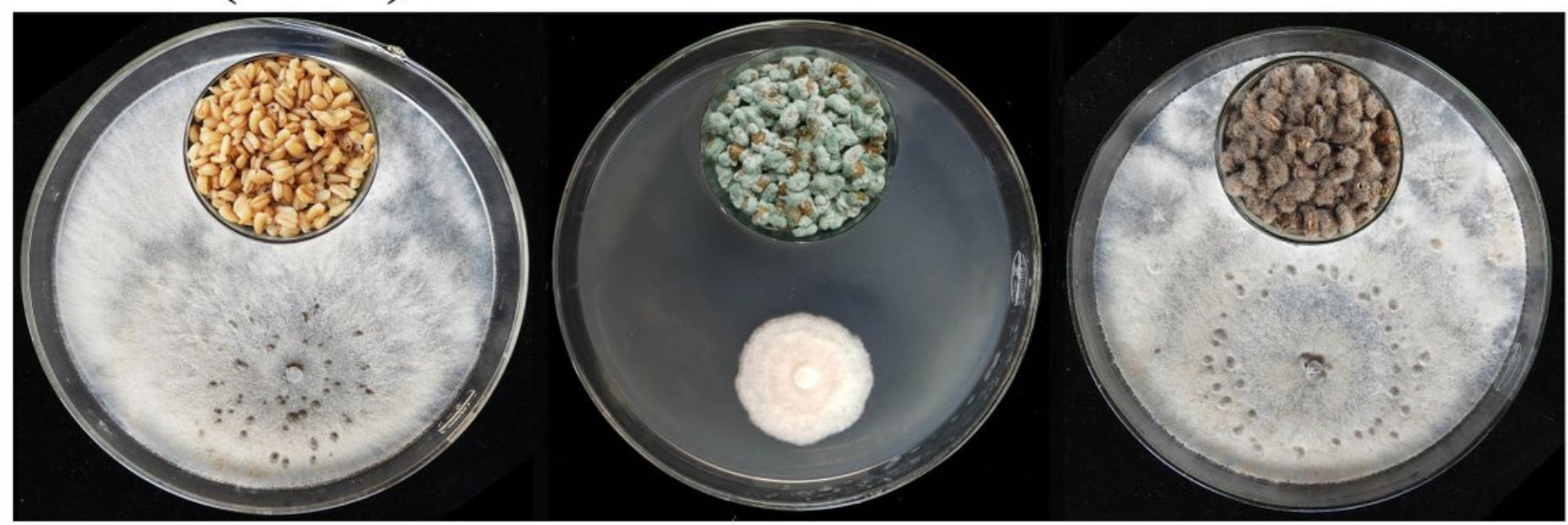

(B)

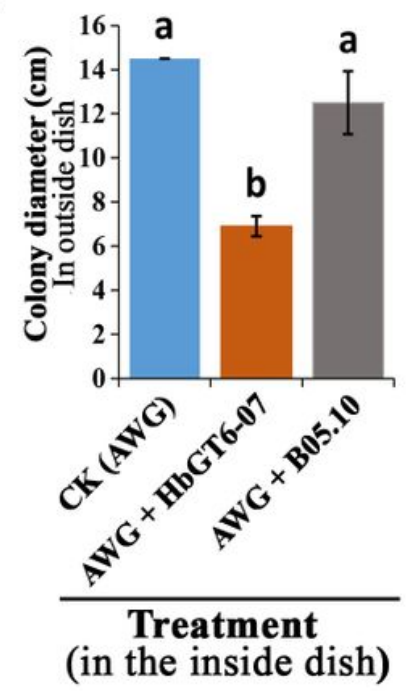

(C)

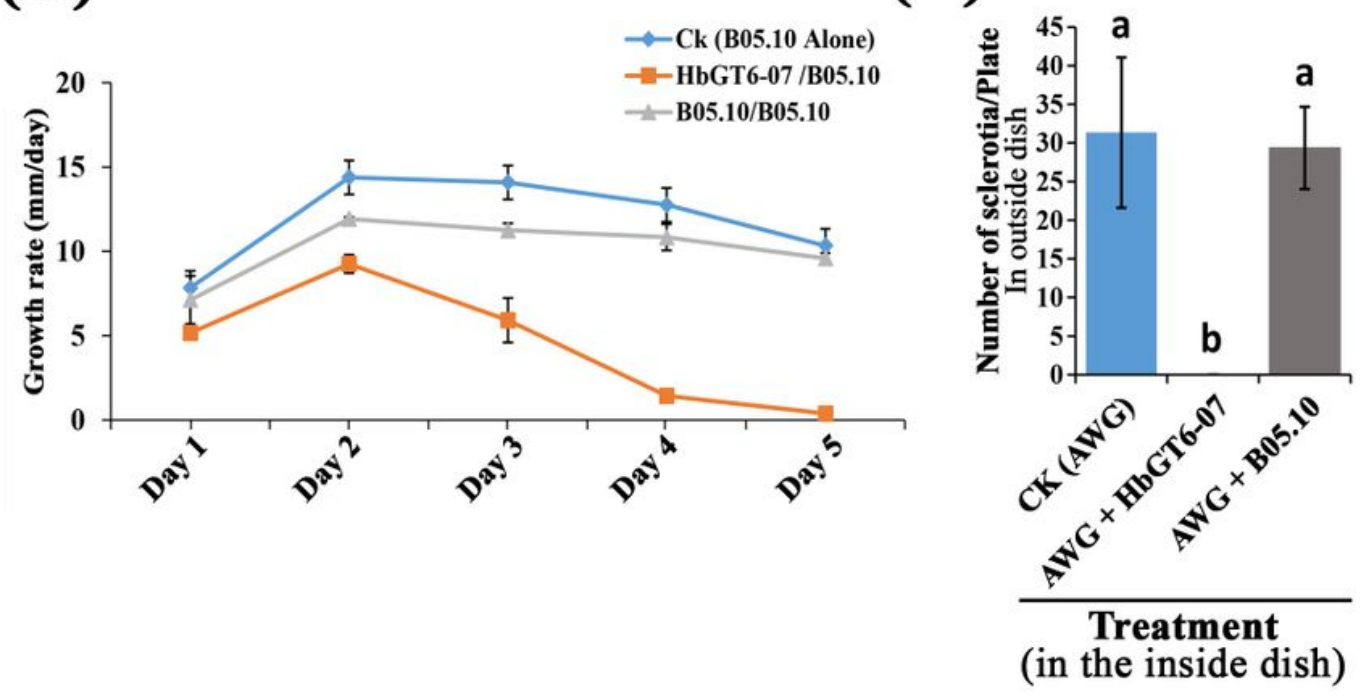

Figure 3

Effect of volatile organic compounds of T. asperellum HbGT6-07 isolate on B. cinerea B05.10. a The initial efficacy of VOCs of isolate T. asperellum HbGT6-07, B. cinerea B05.10 and AWG designated as control (CK). b Indicates colony diameter of AWG+HbGT6-07 and AWG+B05.10 isolates compare to treated and non-treated dishes CK (AWG). c Culture growth rate after 5 days. $d$ The limited number of sclerotia were developed with an average colony size on the dish of isolates AWG+HbGT6-07 
(A)

\section{Ck (AWG) \\ AWG+HbGT6-07 \\ AWG+A367}

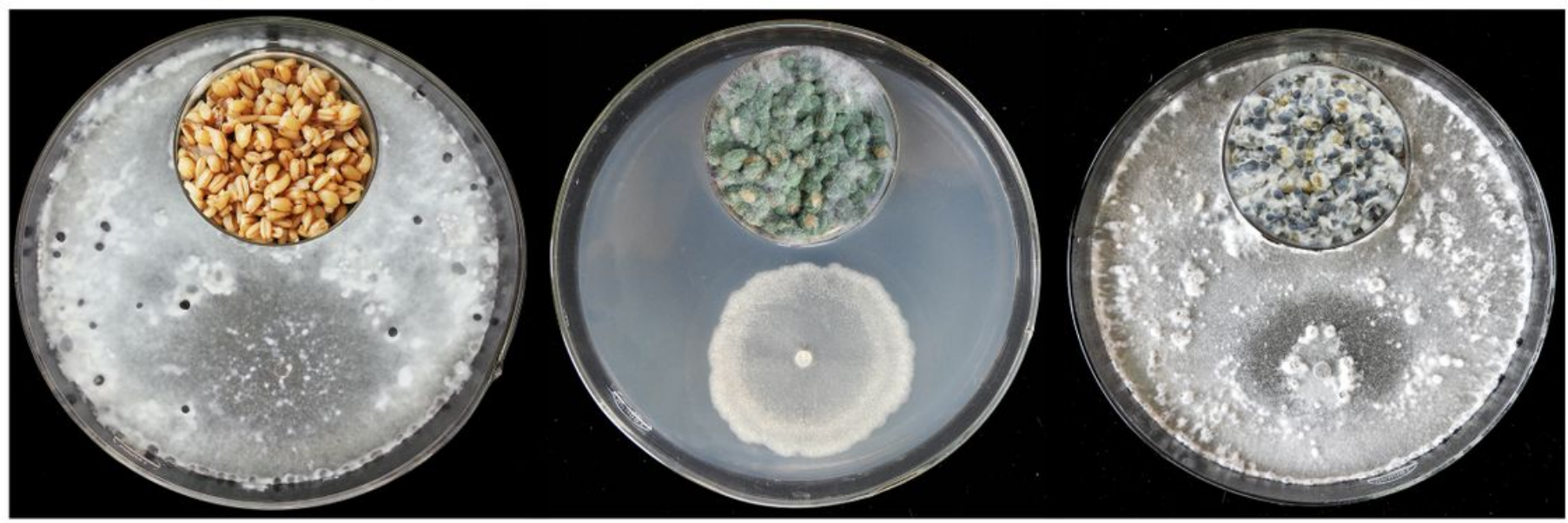

(B)

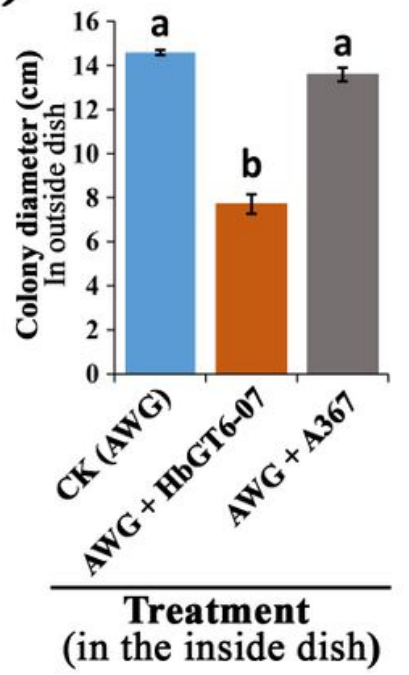

(C)

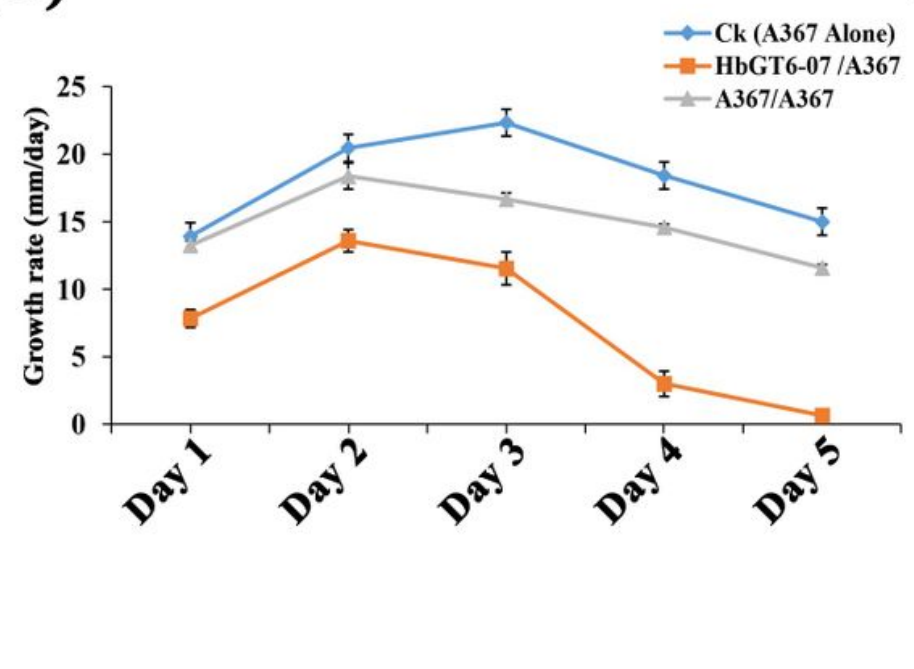

(D)

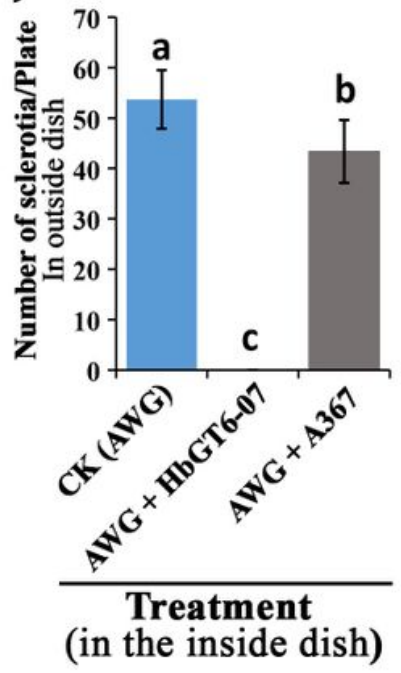

\section{Figure 4}

Effect of volatile organic compounds of T. asperellum HbGT6-07 isolate on S. sclerotiorum A367. a The initial efficacy of VOCs of isolate T. asperellum HbGT6-07, S. sclerotiorum A367. b Indicates colony diameter of AWG+HbGT6-07 and AWG+A367 isolates compare to treated and non-treated dishes $\mathrm{CK}$ (AWG). c Culture growth rate after 5 days. $d$ The limited number of sclerotia were developed with an average colony size on the dish of isolates AWG+HbGT6-07 


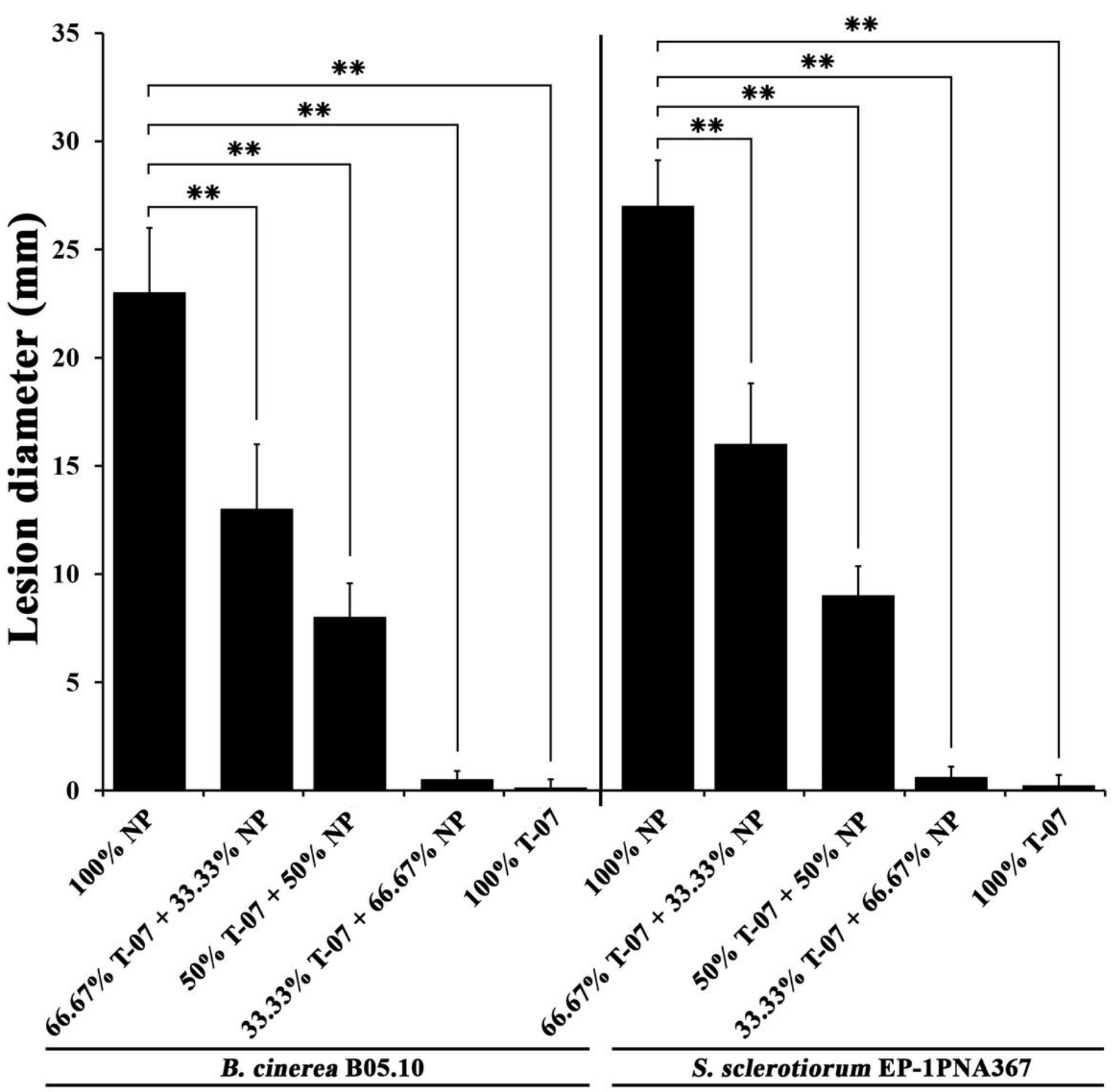

Figure 5

Biocontrol assay of disease suppression by isolate HbGT6-07 on rapeseed leaves. The hyphal fragments (HbGT6-07:B05.10) with the treatment level at ratios of 33.33:66.67, 50:50 and 66.67:33.33 was reduced the leaf lesion diameter of 43,65 and $97 \%$ where $\mathrm{HbGT6-07:A367}$ fragments moderately reduced lesion diameter of 16,9 and $55 \%$, respectively 
(A)
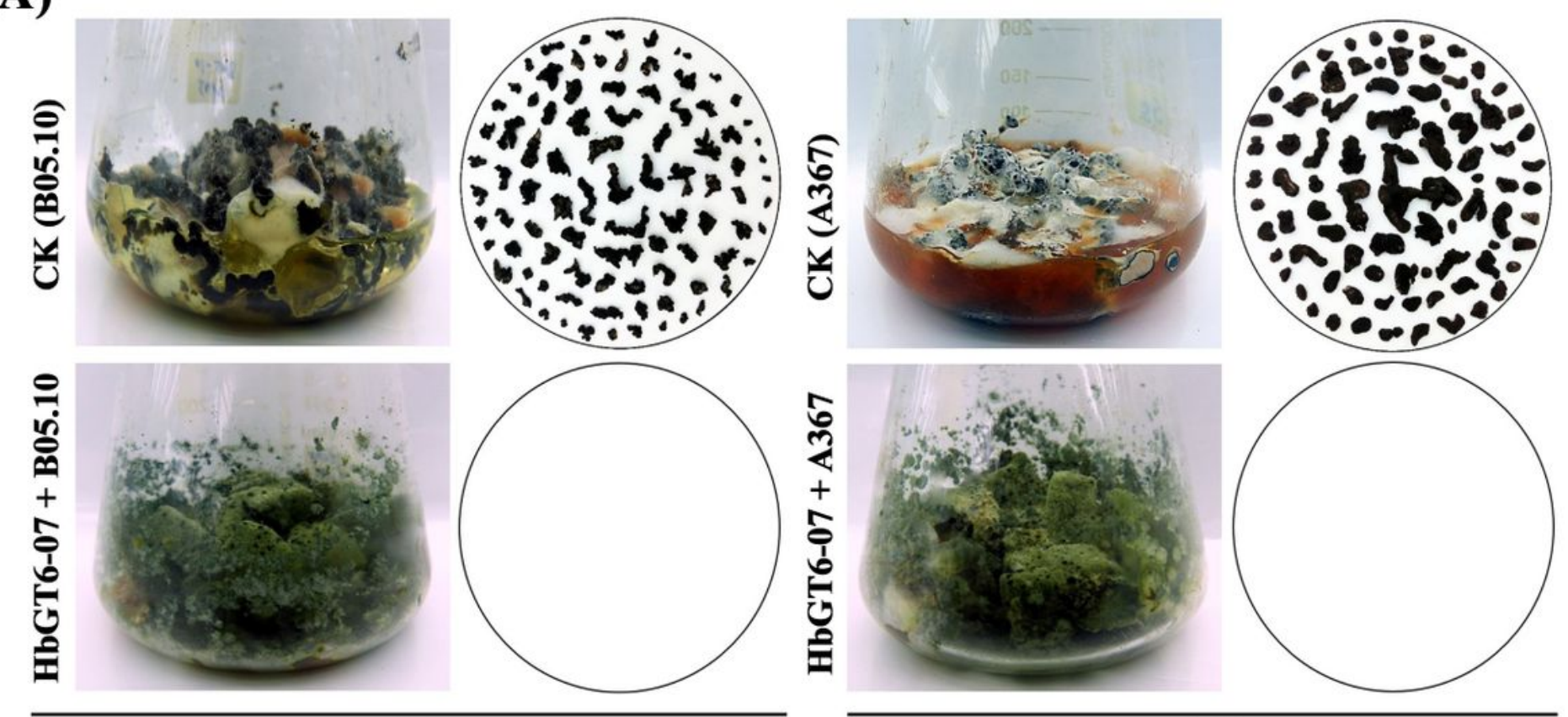

(B)

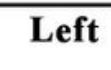

(C)
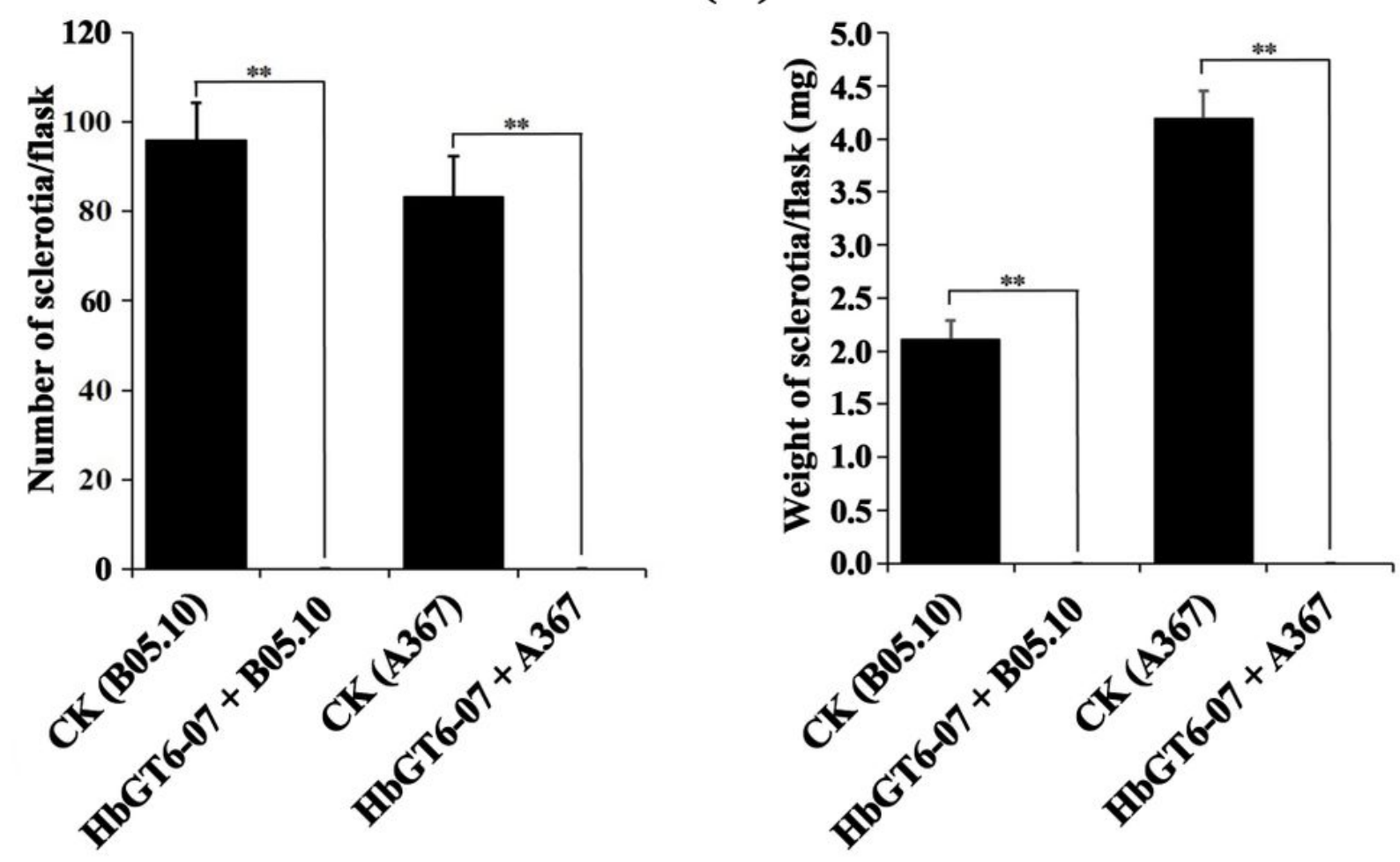

Figure 6

Suppression of sclerotia formation with two different culture conditions a (HbGT6-07+B05.10 and HbGT6-07+A367). b Mixed culture showed significant reduction of sclerotia as compare to for B05.10 and A367. c The dry weight data of sclerotia production revealed HbGT6-07 isolates completely inhibit the sclerotia production 
RT: $0.00-35.00$

\section{Control}

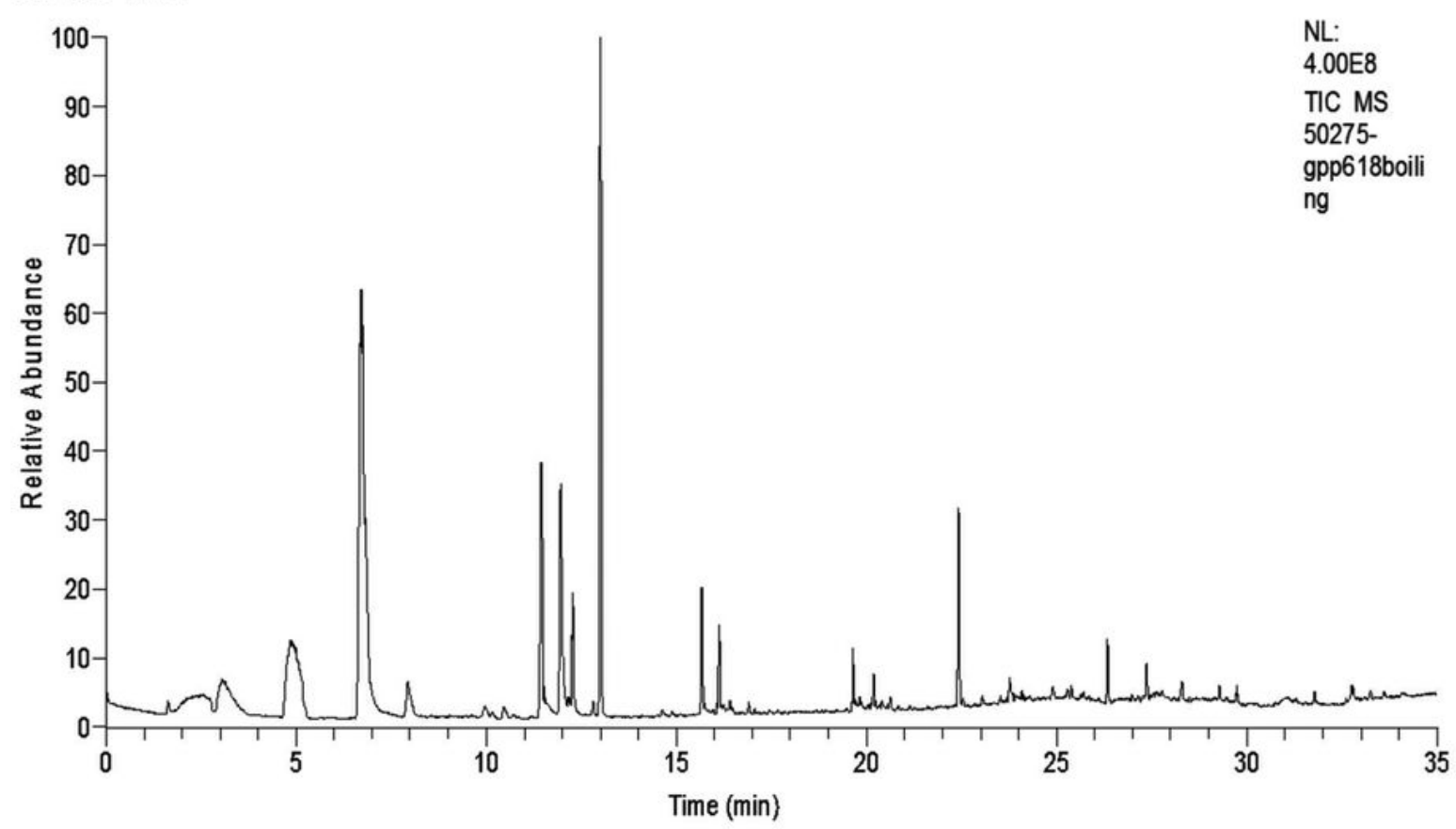

RT: $0.00-35.00$

\section{T. asperellum HbGT6-07}

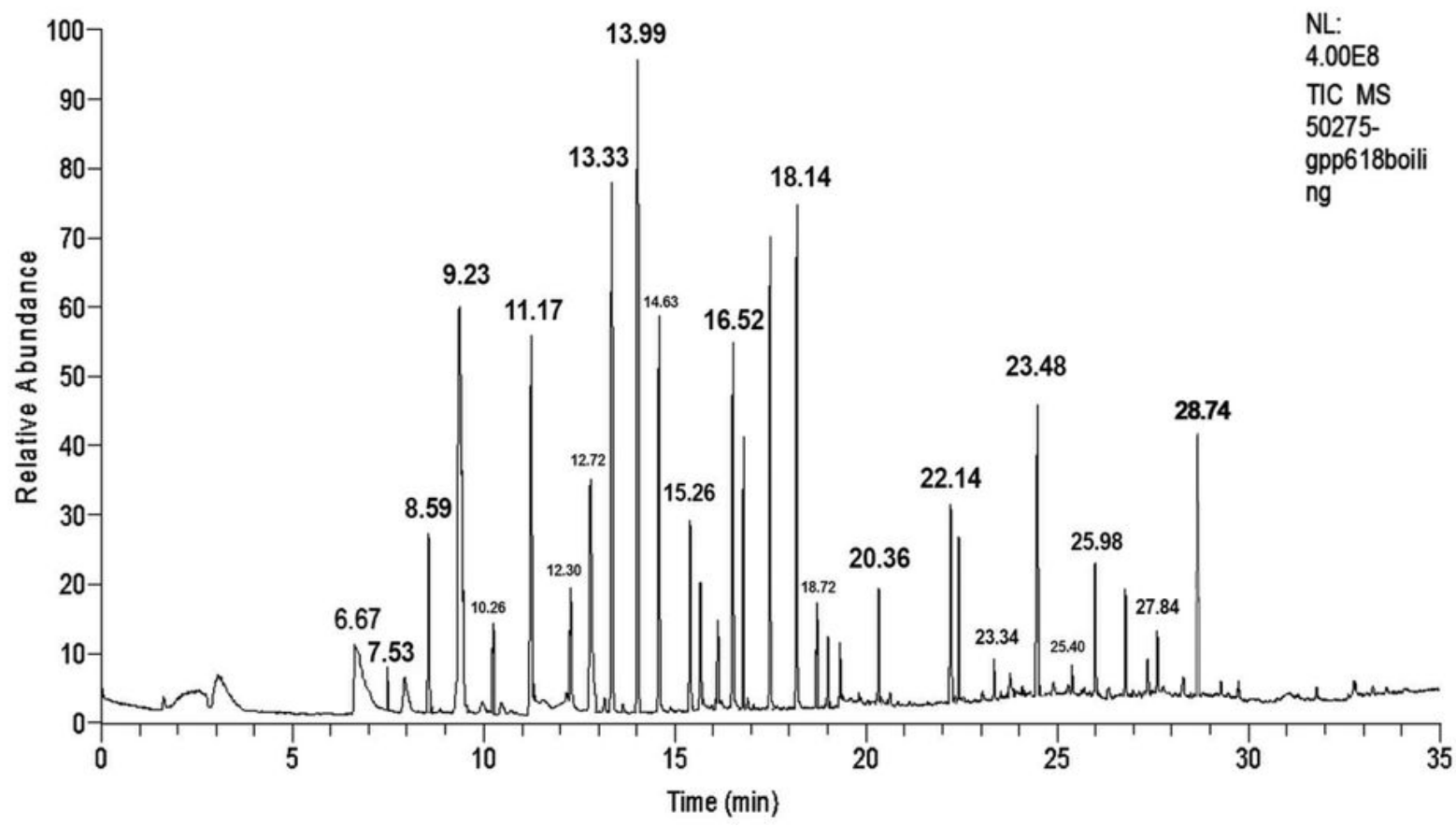

Figure 7

GC-MS profiling of volatile organic compounds emitted by the isolates T. asperellum HbGT6-07 


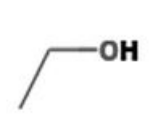<smiles>CC(C)=O</smiles>

1<smiles>CCCC(=O)O</smiles>

2<smiles>C=CC(CC)CCCC</smiles>

9

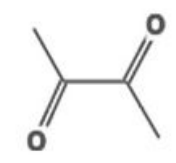

3<smiles>CC(C)CC(=O)O</smiles>

11<smiles>CC(=O)O</smiles>

4<smiles>CCc1ccccc1</smiles>

12<smiles>CC(C)CC=O</smiles>

5<smiles>CCC(C)C=O</smiles>

6<smiles>CC(C)CCO</smiles>

7<smiles>CC(C)C(=O)O</smiles>

8<smiles>CCCCCCCCCCCCCCCCC(C)CCCCCC</smiles>

17

18

19<smiles>CCCCC(CC)CC</smiles>

20<smiles>Cc1ccccc1C</smiles>

13<smiles>CCCCCC(C)C</smiles>

14<smiles>C=Cc1ccccc1</smiles>

15

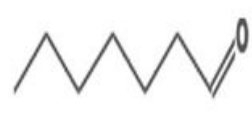

16

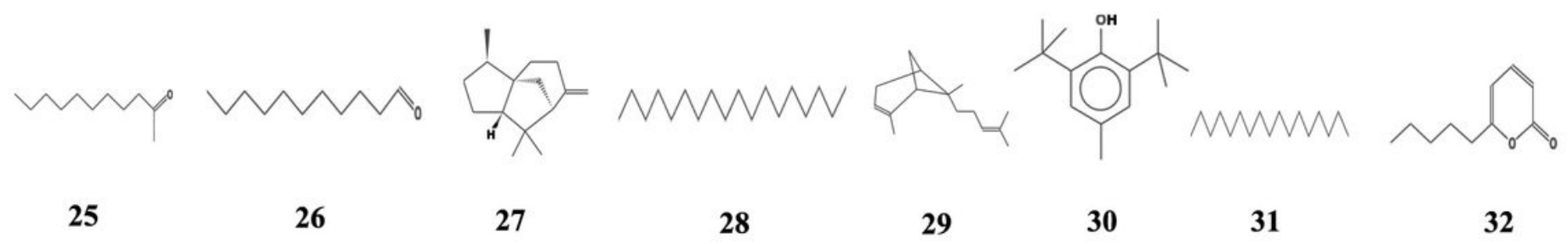

\section{Figure 8}

Structure of thirty-two different volatile organic compounds emitted by the isolates T. asperellum HbGT607

\section{Supplementary Files}

This is a list of supplementary files associated with this preprint. Click to download.

- SupplementaryMaterials..docx 